\section{Audiology \\ Neurotology}

Audiol Neurotol 2017;22:236-258

DOI: $10.1159 / 000481767$
Received: November 29, 2016

Accepted: September 21, 2017

Published online: December 21, 2017

\title{
Quality of Life and Cost-Effectiveness of Cochlear Implants: A Narrative Review
}

\author{
Matthew G. Crowson ${ }^{c}$ Yevgeniy R. Semenov ${ }^{a}$ Debara L. Tuccic John K. Niparko ${ }^{b}$ \\ ${ }^{a}$ Department of Otolaryngology, Head and Neck Surgery, Johns Hopkins University School of Medicine, Baltimore, MD, \\ ${ }^{b}$ Department of Otolaryngology, Head and Neck Surgery, University of Southern California, Los Angeles, CA, and \\ 'Division of Head and Neck Surgery and Communication Sciences, Duke University Medical Center, Durham, NC, USA
}

\section{Keywords \\ Quality of life · Health utility · Costs · Savings · Cost-utility · \\ Cost-benefit $\cdot$ Cost-effectiveness}

\begin{abstract}
Objectives: To review evidence regarding the health-related quality of life (HRQoL) and cost-effectiveness of unilateral and bilateral cochlear implantation $(\mathrm{Cl})$ among children and adults with severe-to-profound hearing loss. Study Design: Narrative review. Methods: Publications related to quality of life (QoL) and costs of care in $\mathrm{Cl}$ were acquired through searches in English-language databases. Studies were included if they had identified the HRQoL attainment, cost of care, cost-utility, or cost-effectiveness associated with $\mathrm{Cl}$. Results: 57 studies were critically reviewed. The QoL outcome metrics used in these articles were divided into 2 categories - generic and condition specific. In studies investigating children, many reported no significant difference in QoL attainment between $\mathrm{Cl}$ recipients and normal-hearing peers. In adults, significant improvements in QoL after implantation and higher QoL than in their nonimplanted (hearing-aided) peers were frequently reported. Studies involving an older adult cohort reported significant improvement in QoL after implantation, which was often independent of au-
\end{abstract}

diological performance. Overall, the calculated cost-utility ratios consistently met the threshold of cost acceptance, indicating acceptable values for expenditures on $\mathrm{Cl}$. Conclusions: Considerable work has been done on the QoL attainment and health economic implications of $\mathrm{Cl}$. Unilateral $\mathrm{Cl}$ across all age groups leads to reported sustained benefits in the recipients' overall and disease-specific QoL. With increased cost associated with bilateral $\mathrm{Cl}$, further study is needed to characterize its costs and benefits with respect to the recipients' health, well-being, and contributions to society.

(c) 2017 S. Karger AG, Basel

\section{Introduction}

Since its introduction into clinical practice, hearing care clinicians have increasingly utilized cochlear implantation (CI) to restore auditory stimulation in selected patients with advanced sensorineural hearing loss. Over the last 15 years, cochlear implant manufacturers have consistently expanded their technologies and device so-

Matthew G. Crowson and Yevgeniy R. Semenov are co-first authors.

Debara L. Tucci, MD

Division of Head and Neck Surgery and Communication Sciences

Duke University Medical Center, Box 3805

Durham, NC 27710 (USA)

E-Mail debara.tucci@duke.edu 
phistication. In this same period, criteria for implantation in candidates of all ages have been broadened based on more refined methods of diagnosis and heightened levels of benefit observed with implantation.

The considerable direct and indirect costs associated with this intervention remain a significant barrier to patients and their families, and present an obstacle to a more widespread adoption of CI technology. However, CI also results in economically valuable quality of life (QoL) improvement [Lindemark et al., 2014; Semenov et al., 2012], enhanced academic achievement [Semenov et al., 2013], and improved vocational outcomes [Emmett and Francis, 2015; McKinnon, 2014] leading to potentially even greater clinical and nonclinical cost savings among CI recipients. As a result, the measurement of the economic benefits of implantation has become essential in making policy decisions. In the United States, one of the first economic analyses investigating CI cost-utility helped convince the Californian MediCal program to include CI in their funding schedule [Harris and Anderson, 1999]. Economic evaluation of health interventions requires the consideration of factors beyond clinical effectiveness, such as the intervention's effects on a patient's level of physical and emotional function, vitality, interpersonal communication, independence in daily living, overall satisfaction with life, and mental health.

Our objective was to perform a narrative review of the literature on the QoL attainment among CI recipients of all ages, and examine cost-effectiveness measures as related to CI. Specifically, we reviewed (1) the characteristics of the studies reporting on QoL attainment and health economic implications of CI, (2) the types of QoL measures used, (3) key results, conclusions, and limitations of the included studies, and (4) outcome differences between individuals implanted with unilateral and bilateral implants.

\section{Methods}

We designed a narrative literature review to assess the healthrelated QoL (HRQoL) attainment and cost-effectiveness of CI in recipients of all ages with severe to profound hearing loss. A secondary goal was to compare the health economic outcomes between unilateral and bilateral implantation. Multiple criteria were agreed upon and used in identifying studies for this review prior to inclusion or exclusion.

\section{Study Design}

Original contributions and review articles from peer-reviewed publications were identified. Both prospective and retrospective study designs, and cross-sectional and longitudinal trials were included.

Quality of Life and Cost-Utility with

Cochlear Implants

\section{Participants}

Studies that enrolled participants with either prelingual or postlingual onset of hearing loss in 3 age categories included children (aged less than 18 years), adults (18-65 years), and older adults (older than 65 years). No exclusions of etiology of hearing loss, duration of hearing loss, timing of CI, or duration of followup were made.

\section{Outcome Measures}

Identified studies with primary outcome measures reported noted:

1. HRQoL metrics utilized in $\mathrm{CI}$ and overall QoL associated with CI

2. Costs and savings associated with CI

3. Cost-effectiveness, cost-benefit, or cost-utility of CI

Secondary outcomes that were also identified:

1. Types of QoL metrics

2. Consideration of bilateral versus unilateral CI

\section{Search Methods for Identification of Studies}

In order to capture the breadth of contemporary literature on all relevant studies investigating CI, the main English language electronic biomedical publication databases were utilized to identify source articles. Specifically, we mined PubMed and EMBASE for classic biomedical literature, periodicals covering audiology and communication sciences (CINAHL), psychology periodicals (PsycINFO and Web of Science), and economic periodicals (EconLit). We used variations of the term "cochlear implantation" and "cost-effectiveness" to identify potential articles of interest. While there were no restrictions on the articles' country of origin, only abstracts available in English were screened for inclusion in the review.

\section{Study Inclusion}

Identified studies using the criteria above were reviewed in 2 stages. In the first stage, titles and abstracts of all retrieved articles were reviewed for relevance. Inclusion criteria were: (1) original peer-reviewed research article or literature review published in a peer-reviewed journal, (2) study abstract available in English, (3) study participants had cochlear implants or were candidates for CI, and (4) study participant ages or age at implantation were clearly identified. After article title and abstracts had been screened, the full-length articles were reviewed. Articles were accepted for review if they met the above 4 criteria and all of the following: (1) study reported on any of the primary outcomes of this review, or (2) study included outcomes of bilateral versus unilateral implantation.

\section{Study Analyses}

For each included article, the basic characteristics of each study were extracted including details of study design, characteristics of participants, interventions, and the primary and secondary outcomes. Only data explicitly reported in the articles were included in the current review. No attempt was made to contact the investigators of included trials for any missing data. When a statistic was provided, we also examined the degree of overlap in the reported confidence intervals where appropriate. The generation of weighted averages of incremental cost-effectiveness ratios was completed by using literature-reported gains and the number of patients included in the pertinent study. If there was no overlap amongst reported statistics, this was taken to indicate the presence of heterogeneity. 


\section{Results}

\section{Study Selection and Common Characteristics}

After subjecting our initial database search to our primary exclusion criteria, 68 articles were included in the final results. Studies used both cross-sectional and longitudinal design to capture QoL and health economic outcomes following CI. The sample size of the 57 studies ranged from 8 to $908 \mathrm{CI}$ recipients (Tables 1-4). Additionally, there was considerable variance in the ages at the time of CI within the 3 age categories considered in this review and the duration of implant use. Most studies did not report age ranges at implantation, but some did report on the standard deviation of age at CI.

\section{QoL Metrics}

The QoL outcome metrics used in these articles could be divided into 2 categories - generic and disease specific. They were then further divided into population-validated and ad hoc QoL instruments designed for the specific use of the given trial. Fifteen of the studies focused on presenting metrics for assessing the QoL attainment of children with cochlear implants (Table 1).

\section{Generic Instruments in Children}

Eight studies reported on generic health utility metrics, which included KINDL ${ }^{\circledR}$ [Huber, 2005; Loy et al., 2010; Warner-Czyz et al., 2009, 2011], visual analog scale (VAS) [Clark et al., 2012; Sach and Barton, 2007], Quality of Well-Being Scale (QWB) [Clark et al., 2012], Child Health and Illness Profile (CHIP) child edition [Clark et al., 2012; Meserole et al., 2014], European Quality of Life Questionnaire in 5 domains (EQ5D) [Clark et al., 2012; Sach and Barton, 2007], Satisfaction with Life Scale (SWLS) [Spencer et al., 2012], and EuroQoL VAS [Sach and Barton, 2007]. A comprehensive review of these surveys is beyond the subject of the current paper and may be found elsewhere [Froberg and Kane, 1989; Zullig et al., 2010]. KINDL ${ }^{\circledR}$ is a 24 -item QoL questionnaire developed in Germany and validated for use in children from 8 to 16 years of age [Ravens-Sieberer and Bullinger, 1998]. It is composed of 6 scales: physiological and psychological well-being, self-esteem, family, friends, and functioning. Both child report and parent-proxy versions are available, and normative values have been established for comparison. As is the case for all questionnaires administered to children, results are limited by the fact that very young children cannot respond, and parents serve as proxy respondents.
The CHIP child edition is a population-validated selfreported QoL instrument for children 6-11 years old [Riley et al., 2004]. It is comprised of 5 domains: satisfaction (with self and health), comfort (emotional and physical symptoms and limitations), resilience (positive activities that promote health), risk avoidance (risky behaviors that influence future health), and achievement (of social expectations in school and with peers). The QWB is a 71-item questionnaire and measures the respondent's overall health status and well-being over the previous 3 days across 4 domains: physical activities, social activities, mobility, and symptom/problem complexes [Seiber et al., 2008].

The EQ5D is a self-administered questionnaire that assesses function in 5 socially relevant domains: mobility, self-care, usual activities, pain-discomfort, and anxiety-depression. The Euro-QoL VAS is a linear visual analog scale that accompanies the EQ5D [Gusi et al., 2010]. The VAS presents a line with grid marks from 0 ("death") to 100 and asks the respondent or a respondent's proxy to draw a line corresponding to the respondent's QoL. Lastly, the SWLS is a short 5-item instrument designed to measure global cognitive judgments of satisfaction with one's life and is not a health-specific metric [Kobau et al., 2010].

\section{Disease-Specific Instruments in Children}

Six studies reported on disease-specific QoL metrics, which include youth QoL deaf and hard of hearing edition (YQoL-DHH) [Meyer et al., 2013], Deaf Identity Scale [Spencer et al., 2012], Children with Cochlear Implants: Parental Perspectives questionnaire [FortunatoTavares et al., 2012; Huttunen et al., 2009], and the Nijmegen Cochlear Implant Questionnaire (NCIQ) [Necula et al., 2013]. The YQoL-DHH is a 32-item questionnaire that assesses hearing loss-related QoL across 3 domains: self-acceptance/advocacy, perceived stigma, and participation [Patrick et al., 2011]. The Deaf Identity Scale is composed of 3 subscales, including hearing identification, deaf identification, and dual identification. Each subscale consisted of 5 statements regarding the individual's desire to associate with and the individual's assumed similarity with deaf, hearing, or both groups [Weinberg and Sterritt, 1986]. The Glasgow Children's Benefit Inventory (GCBI, [Sparreboom et al., 2012]; Table 2) is used to measure and evaluate a child's health benefit retrospectively, after an otological intervention. Answers are provided on a 5-point Likert scale and converted to a 200-point scale which ranges from -100 (maximal harm) to +100 (maximal benefit). The GCBI can also be analyzed according to 4 domains, including emotion, physical health, learning, and vitality. 
Table 1. Quality of life outcomes following unilateral cochlear implantation

\begin{tabular}{|c|c|c|c|c|c|}
\hline Study & $\begin{array}{l}\text { Sample size }(n), \text { gender } \\
\text { ( } n \text { female), mean age at CI/ } \\
\text { time of study }\end{array}$ & Study type & $\begin{array}{l}\text { Primary outcome } \\
\text { metric }\end{array}$ & $\begin{array}{l}\text { Geographic } \\
\text { origin }\end{array}$ & Findings \\
\hline \multicolumn{6}{|c|}{ Studies in children } \\
\hline $\begin{array}{l}\text { Clark et al., } \\
2012\end{array}$ & $\begin{array}{l}n=188 \text { ( } 98 \text { female), } \\
\text { undergoing CI before } 5 \\
\text { years of age with an } \\
\text { average age of } 26.7 \text { (14.5) } \\
\text { months at implantation }\end{array}$ & $\begin{array}{l}\text { Prospective, } \\
\text { longitudinal study } \\
\text { with } 4 \text { years of } \\
\text { follow-up }\end{array}$ & $\begin{array}{l}\text { VAS, VAS-D, QWB, } \\
\text { CHIP-Child edition, } \\
\text { and EQ5D }\end{array}$ & USA & $\begin{array}{l}\text { Baseline deficits of CI relative to NH peers were } \\
\text { larger in developmental factors than in QoL } \\
\text { No significant QoL differences were observed } \\
\text { in CI children after } 4 \text { years as compared to NH } \\
\text { peers }\end{array}$ \\
\hline $\begin{array}{l}\text { Loy et al., } \\
2010\end{array}$ & $\begin{array}{l}n=52 \text { ( } 29 \text { female) } \\
\text { implanted at } 3.4(2.1) \text { years } \\
\text { and } 9.1 \text { (1.1) years of age at } \\
\text { time of study } \\
n=34 \text { ( } 23 \text { female) } \\
\text { implanted at } 5.8(4.0) \text { years } \\
\text { and } 13.7 \text { (1.4) years of age } \\
\text { at time of study }\end{array}$ & Cross-sectional & $\begin{array}{l}\text { Kid KINDL }{ }^{\circledR} \text { and } \\
\text { Kiddo KINDL }^{\circledR}\end{array}$ & USA & $\begin{array}{l}\text { Earlier implantation and longer use of implants } \\
\text { resulted in higher QoL scores }\end{array}$ \\
\hline $\begin{array}{l}\text { Meserole } \\
\text { et al., } 2013\end{array}$ & $\begin{array}{l}n=129 \text { ( } 77 \text { female), } \\
\text { undergoing CI before } \\
5 \text { years of age with an } \\
\text { average age of } 8.0(1.3) \\
\text { years at time of study }\end{array}$ & $\begin{array}{l}\text { Prospective, } \\
\text { longitudinal study } \\
\text { with } 6 \text { years of } \\
\text { follow-up }\end{array}$ & CHIP-Child edition & USA & $\begin{array}{l}\text { QoL is comparable between CI recipients and } \\
\text { their NH peers, while their parents reported } \\
\text { similar scores when compared with } \\
\text { socioeconomically comparable families of } \mathrm{NH} \\
\text { children }\end{array}$ \\
\hline $\begin{array}{l}\text { Meyer et al., } \\
2013\end{array}$ & $\begin{array}{l}n=63(31 \text { female }) \\
\text { implanted at } 62.8(10-180) \\
\text { months of age }\end{array}$ & Cross-sectional & YQoL-DHH & USA & $\begin{array}{l}\text { Compared outcomes of implanted versus } \\
\text { nonimplanted children using HA or no } \\
\text { assistive technology } \\
\text { Youth using no technology or using cochlear } \\
\text { implants tended to score higher than those } \\
\text { using HA in mainstream schools (with or } \\
\text { without deaf and hard-of-hearing programs) } \\
\text { and in schools for the deaf However, the no- } \\
\text { technology group consistently outperformed } \\
\text { implanted children in QoL attainment }\end{array}$ \\
\hline $\begin{array}{l}\text { Schorr et al., } \\
2009\end{array}$ & $\begin{array}{l}n=37 \text { ( } 21 \text { female) } \\
\text { congenitally deaf children } \\
\text { implanted at } 3.0(0.2-8.3) \\
\text { years of age and } 9(5-14) \\
\text { years of age at time of } \\
\text { study }\end{array}$ & Cross-sectional & Ad hoc instrument & USA & $\begin{array}{l}\text { QoL was reported as significantly improved } \\
\text { with the cochlear implant, and increased QoL } \\
\text { predicted better performance on the emotion } \\
\text { identification task } \\
\text { QoL was positively associated with age at first } \\
\text { amplification supporting the importance of } \\
\text { early detection and intervention in HL }\end{array}$ \\
\hline $\begin{array}{l}\text { Spencer et al., } \\
2012\end{array}$ & $\begin{array}{l}n=41 \text { ( } 22 \text { female) } \\
\text { implanted at } 7.2(3.8) \text { years } \\
\text { and } 21.9(3.8) \text { years of age } \\
\text { at time of study }\end{array}$ & $\begin{array}{l}\text { Longitudinal with } \\
\text { over } 10 \text { years of } \\
\text { follow-up }\end{array}$ & $\begin{array}{l}\text { Satisfaction-with-Life } \\
\text { scale, Deaf Identity } \\
\text { scale }\end{array}$ & USA & $\begin{array}{l}\text { Compared with their } \mathrm{NH} \text {, adult-age peers, CI } \\
\text { recipients had high educational achievement } \\
\text { and reported a very high satisfaction with life } \\
\text { Also, most of the individuals endorsed a dual } \\
\text { identity, indicating they feel just as comfortable } \\
\text { with deaf individuals as they do with hearing } \\
\text { individuals }\end{array}$ \\
\hline $\begin{array}{l}\text { Warner-Czyz } \\
\text { et al., } 2009\end{array}$ & $\begin{array}{l}n=50 \text { ( } 22 \text { female), } \\
\text { implanted at } 2.5(1.5) \text { years } \\
\text { and } 5.8(1.1) \text { years of age at } \\
\text { time of study }\end{array}$ & $\begin{array}{l}\text { Cross-sectional - } \\
\text { CI vs. NH peers }\end{array}$ & Kiddy KINDL ${ }^{\circledR}$ & USA & $\begin{array}{l}\text { Implanted children rated their overall QoL } \\
\text { significantly more positively than did their } \\
\text { parents, and child ratings did not differ } \\
\text { significantly from } \mathrm{NH} \text { children } \\
\text { Overall, QoL correlated inversely with length of } \\
\text { implant experience and chronologic age, but } \\
\text { did not correlate with implantation age }\end{array}$ \\
\hline
\end{tabular}


Table 1 (continued)

\begin{tabular}{|c|c|c|c|c|c|}
\hline Study & $\begin{array}{l}\text { Sample size }(n), \text { gender } \\
\text { ( } n \text { female), mean age at CI/ } \\
\text { time of study }\end{array}$ & Study type & $\begin{array}{l}\text { Primary outcome } \\
\text { metric }\end{array}$ & $\begin{array}{l}\text { Geographic } \\
\text { origin }\end{array}$ & Findings \\
\hline $\begin{array}{l}\text { Warner-Czyz } \\
\text { et al., } 2011\end{array}$ & $\begin{array}{l}n=140((72 \text { female }) \\
\text { implanted at } 3.7(2.8) \text { years } \\
\text { and } 9.0(3.2) \text { years of age at } \\
\text { time of study } \\
\text { Implantation age for } 3 \\
\text { subgroups: } 2.5(1.4), 3.4 \\
(2.1) \text {, and } 5.7(3.9) \text { years } \\
\text { for youngest, middle, and } \\
\text { oldest study groups }\end{array}$ & Cross-sectional & $\begin{array}{l}\mathrm{KINDL}^{\circledR} \text {, ad hoc } \\
\text { instrument }\end{array}$ & USA & $\begin{array}{l}\text { The youngest group }(4-7 \text { years: } 82.8) \text { rated } \\
\text { generic QoL significantly more positively than } \\
\text { older children }(8-11 \text { years: } 75.3 ; 12-16 \text { years: } \\
70.4) \\
\text { Similar significant results emerged on the } \\
\text { overall CI module }(4-7 \text { years: } 79.8 ; 8-11 \text { years: } \\
77.8 ; 12-16 \text { years: } 71.3)\end{array}$ \\
\hline $\begin{array}{l}\text { Edwards et al., } \\
2012\end{array}$ & $\begin{array}{l}n=88 \text { ( } 37 \text { female) } \\
\text { implanted at } 3.8(2.1) \text { years } \\
\text { and } 11.1(2.0) \text { years of age } \\
\text { at time of study }\end{array}$ & $\begin{array}{l}\text { Cross-sectional - } \\
\text { CI with additional } \\
\text { comorbidities vs. } \\
\text { no additional } \\
\text { comorbidities }\end{array}$ & Ad hoc instrument & UK & $\begin{array}{l}\text { QoL of the } 42 \% \text { of the children who had } \\
\text { additional needs was rated poorer than that of } \\
\text { the children without additional needs on } 3 \text { of } \\
\text { the } 4 \text { subscales as well as on the total QoL rating } \\
\text { Despite this, however, most parents reported } \\
\text { that their child's QoL had improved } \\
\text { "moderately" or "very much," irrespective of } \\
\text { whether they had additional needs }\end{array}$ \\
\hline Huber, 2005 & $\begin{array}{l}n=18 \text { ( } 6 \text { female) } \\
\text { implanted at } 4.3(2.0) \text { years } \\
\text { and } 10.5(1.4) \text { years of age } \\
\text { at time of study } \\
n=11 \text { ( } 2 \text { female) } \\
\text { implanted at } 7.6(1.8) \text { years } \\
\text { and } 14.5 \text { (1.2) years of age } \\
\text { at time of study }\end{array}$ & Cross-sectional & $\mathrm{KINDL}^{\circledR}$ & Austria & $\begin{array}{l}\text { The younger group reached a significantly } \\
\text { lower total QoL compared to NH peers, } 64.6 \\
\text { (8.9) vs. } 76.8(8.6) \text {, respectively } \\
\text { This result differs significantly from } \\
\text { parent-proxy responses of } 80.8(5.4) \\
\text { There was no significant QoL difference } \\
\text { between the older study group, their NH peers, } \\
\text { and parental ratings: } 72.1(10.3) \text { in the } \\
\text { self-rating, } 73.5 \text { ( } 8.8) \text { for NH peers, and } \\
76.3(10.2) \text { for parental ratings }\end{array}$ \\
\hline $\begin{array}{l}\text { Huttunen } \\
\text { et al., } 2009\end{array}$ & $\begin{array}{l}n=36 \text { ( } 19 \text { females) } \\
\text { implanted at } 3.4(2.3) \text { years } \\
\text { and } 5(2) \text { years of age at } \\
\text { time of study }\end{array}$ & Cross-sectional & CCIPP & Finland & $\begin{array}{l}\text { Parents were most satisfied with improved/ } \\
\text { expanded social relations, improved } \\
\text { communication (the development of spoken } \\
\text { language), general functioning with the help of } \\
\text { hearing, and improved self-reliance of the child } \\
\text { following CI }\end{array}$ \\
\hline $\begin{array}{l}\text { Necula et al., } \\
2013\end{array}$ & $\begin{array}{l}n=84 \text { (gender not } \\
\text { reported) implanted at } 5.2 \\
\text { (3.4) years and } 7.6(4.2) \\
\text { years of age at current } \\
\text { study }\end{array}$ & $\begin{array}{l}\text { Cross-sectional - } \\
\text { young and older CI } \\
\text { groups vs. HA peers }\end{array}$ & NCIQ & Romania & $\begin{array}{l}\text { QoL was positively correlated with auditory } \\
\text { performance and speech intelligibility, but } \\
\text { negatively correlated with implantation age } \\
\text { CI recipients outperformed HA users in } \\
\text { auditory performance and speech production }\end{array}$ \\
\hline $\begin{array}{l}\text { Sach et al., } \\
2007\end{array}$ & $\begin{array}{l}n=222(109 \text { female) aged } \\
9.3(3.6) \text { years at time of } \\
\text { study } \\
\text { Children implanted at } \\
<4 \text { years of age }(108) \text { and } \\
>4 \text { years of age }(114)\end{array}$ & Cross-sectional & $\begin{array}{l}\text { EQ5D, VAS, } \\
\text { EuroQol VAS }\end{array}$ & UK & $\begin{array}{l}\text { Regression analysis indicated lower EQ5D } \\
\text { scores for: (1) children with an additional } \\
\text { disability, (2) male children, (3) those with a } \\
\text { lower level of auditory perception, and (4) those } \\
\text { whose parents left school before the age of } 18 \\
\text { EuroQol VAS, the mean difference between } \\
\text { pre- and postimplantation score, was } 0.14 \text {, } \\
\text { compared to } 0.35 \text { for the QoL VAS, } \\
\text { demonstrating that parents tended not to see } \\
\text { HRQoL and QoL as equivalent, though both } \\
\text { were strongly correlated }\end{array}$ \\
\hline $\begin{array}{l}\text { Stacey et al., } \\
2006\end{array}$ & $\begin{array}{l}n=468 \text { stratified into } \\
6 \text { groups by age at } \\
\text { implantation }(<5 \text { or } 5 \text { and } \\
\text { above }) \text { and duration of CI } \\
\text { use }(<2,2-4 \text {, and } \geq 4)\end{array}$ & $\begin{array}{l}\text { Cross-sectional - } \\
\text { CI vs. nonimplanted } \\
\text { controls }\end{array}$ & Ad hoc instrument & UK & $\begin{array}{l}\text { CI was consistently associated with advantages } \\
\text { in auditory performance and spoken } \\
\text { communication skills, but less consistently } \\
\text { associated with advantages in educational } \\
\text { achievements and QoL } \\
\text { Only children implanted under } 5 \text { years of age and } \\
\text { with } 4 \text { years of CI use had consistently improved } \\
\text { QoL as compared to nonimplanted children }\end{array}$ \\
\hline
\end{tabular}


Table 1 (continued)

\begin{tabular}{|c|c|c|c|c|c|}
\hline Study & $\begin{array}{l}\text { Sample size }(n) \text {, gender } \\
\text { ( } n \text { female), mean age at CI/ } \\
\text { time of study }\end{array}$ & Study type & $\begin{array}{l}\text { Primary outcome } \\
\text { metric }\end{array}$ & $\begin{array}{l}\text { Geographic } \\
\text { origin }\end{array}$ & Findings \\
\hline
\end{tabular}

\section{Studies in adults}

$\begin{array}{ll}\text { Chung et al., } & n=283 \text { (163 female) } \\ 2012 & \text { implanted at } 52.9(15.1)\end{array}$

years of age
Prospective, SF-36 Canada longitudinal study with 1 year of follow-up

\begin{tabular}{|c|c|c|c|c|c|}
\hline $\begin{array}{l}\text { Cohen et al., } \\
2004\end{array}$ & $\begin{array}{l}n=24 \text { (16 female) } \\
\text { implanted at } 62.8(7.3) \\
\text { years and } 67.2(8.3) \text { years } \\
\text { of age at study }\end{array}$ & $\begin{array}{l}\text { Cross-sectional - } \\
\text { CI vs. HA controls }\end{array}$ & NCIQ & USA & $\begin{array}{l}\text { CI users showed twice as much overall QoL } \\
\text { Significantly greater QoL benefit in CI than HA } \\
\text { users across physical, psychological, and social } \\
\text { subdomains of the questionnaire }\end{array}$ \\
\hline $\begin{array}{l}\text { Damen et al., } \\
2007\end{array}$ & $\begin{array}{l}n=37 \text { (20 female) } \\
\text { implanted at } 45.2(5.4) \\
\text { years and } 55.1(16.0) \text { years } \\
\text { of age at time of study } \\
n=22(14 \text { female) } \\
\text { implanted at } 57.0(13.4) \\
\text { years and } 61.5(13.1) \text { years } \\
\text { of age at time of study }\end{array}$ & $\begin{array}{l}\text { Longitudinal, with } \\
\text { at least } 6 \text { years of } \\
\text { follow-up - } \\
\text { compared } 2 \text { CI } \\
\text { (younger and older) } \\
\text { groups with } \\
\text { nonimplanted peers }\end{array}$ & NCIQ, HUI3, SF-36 & $\begin{array}{l}\text { The } \\
\text { Netherlands }\end{array}$ & $\begin{array}{l}\text { Beneficial impact of implantation on QoL, } \\
\text { effect remained stable across } 6 \text { years } \\
\text { Implanted adults attained higher QoL than } \\
\text { nonimplanted study participants }\end{array}$ \\
\hline $\begin{array}{l}\text { Fuller et al., } \\
2013\end{array}$ & $\begin{array}{l}n=22(16 \text { female }) \\
\text { implanted at } 41.2(14.3) \\
\text { years and } 47.4(15.0) \text { years } \\
\text { of age at time of study }\end{array}$ & Cross-sectional & $\begin{array}{l}\text { Ad hoc instrument } \\
\text { regarding perception } \\
\text { and enjoyment of } \\
\text { music, SSQ, NCIQ, } \\
\text { CIFI }\end{array}$ & $\begin{array}{l}\text { The } \\
\text { Netherlands }\end{array}$ & $\begin{array}{l}\text { Mean total scores on QoL of implanted adults } \\
\text { were: NCIQ - } 72(44-92) \text {, CIFI - } 11(4-19) \text {, } \\
\text { and SSQ - } 4.4(0.6-7.6) \\
\text { No significant correlations were shown between } \\
\text { music perception and QoL scores }\end{array}$ \\
\hline $\begin{array}{l}\text { Harris and } \\
\text { Anderson, } \\
1999\end{array}$ & $\begin{array}{l}n=9(3 \text { women }), \text { age range } \\
23-59 \text { years }\end{array}$ & Longitudinal & CES-D, SLA, QWB & USA & $\begin{array}{l}\text { Overall, there was no significant change in } \\
\text { scores on the CES-D, but a measured increase } \\
\text { in quality of life metrics on the SLA and QWB }\end{array}$ \\
\hline $\begin{array}{l}\text { Klop et al., } \\
2007\end{array}$ & $\begin{array}{l}n=8(5 \text { female }) \text { pre- } \\
\text { lingually hearing-impaired } \\
\text { adults implanted at } 36.0 \\
(21-55) \text { years of age }\end{array}$ & Longitudinal & HUI2, NCIQ, VAS & $\begin{array}{l}\text { The } \\
\text { Netherlands }\end{array}$ & $\begin{array}{l}\text { Compared QoL before and after implantation } \\
\text { Significant improvement was measured at } 4 \\
\text { months afterimplantation, but no additional } \\
\text { significant changes occurred thereafter }\end{array}$ \\
\hline $\begin{array}{l}\text { Klop et al., } \\
2008\end{array}$ & $\begin{array}{l}n=44(29 \text { female }) \\
\text { implanted at } 54.7(15.5) \\
\text { years of age }\end{array}$ & $\begin{array}{l}\text { Longitudinal with } \\
1 \text { year of follow-up }\end{array}$ & HUI3, NCIQ & $\begin{array}{l}\text { The } \\
\text { Netherlands }\end{array}$ & $\begin{array}{l}\text { Significant improvement in QoL following } \\
\text { implantation, with the largest improvement in } \\
\text { categories concerning physical functioning } \\
\text { (hearing) } \\
\text { Most QoL benefit observed within } 4 \text { months of } \\
\text { implantation } \\
\text { HUI2 increased from } 0.68(0.14) \text { to } 0.83(0.12) \text {, } \\
\text { and NCIQ increased from } 44.5 \text { (12.7) to } 70.3 \\
(10.0)\end{array}$ \\
\hline $\begin{array}{l}\text { Kuthubutheen } \\
\text { et al., } 2015\end{array}$ & $\begin{array}{l}n=30 \text { ( } 16 \text { female) } 56 \text { years } \\
\text { of age at time of study } \\
\text { Mean duration of } \\
\text { unilateral CI use was } \\
4 \text { years }\end{array}$ & Cross-sectional & $\begin{array}{l}\text { HUI3, EQ5D, TTO, } \\
\text { VAS }\end{array}$ & $\begin{array}{l}\text { Canada } \\
\text { and USA }\end{array}$ & $\begin{array}{l}\text { Individuals with unilateral CI scored } \\
\text { consistently higher on all measures of QoL } \\
\text { attainment than nonimplanted controls: } \\
\text { gaining HUI3 }(0.270) \text {, EQ5D }(0.140) \text {, VAS } \\
(0.130) \text {, and TTO }(0.170)\end{array}$ \\
\hline
\end{tabular}

Quality of Life and Cost-Utility with Cochlear Implants
Significant improvement in QoL was observed before and after implantation across 5 of 8 domains of SF-36 (vitality, physical role functioning, mental health, emotional role functioning, and social functioning) Younger implant recipients outperformed older recipients in several domains

rs showed twice as users across physical, psychological, and social Beneficial impact of implantation on QoL Implanted adults attained higher QoL than nonimplanted study participants (0.130), and TTO (0.170) 
Table 1 (continued)

\begin{tabular}{|c|c|c|c|c|c|}
\hline Study & $\begin{array}{l}\text { Sample size }(n) \text {, gender } \\
(n \text { female }), \text { mean age at CI/ } \\
\text { time of study }\end{array}$ & Study type & $\begin{array}{l}\text { Primary outcome } \\
\text { metric }\end{array}$ & $\begin{array}{l}\text { Geographic } \\
\text { origin }\end{array}$ & Findings \\
\hline
\end{tabular}

Mo et al., $\quad n=27$ (15 female) at $57.6 \quad$ Longitudinal with PQLF, Scores were significantly improved following

$2005 \quad$ (14.5) years of age at time of study

The mean duration of deafness before CI was 8.5

(10.3) years

$\begin{array}{ll}12-15 \text { months of } & \text { HSCL-25, } \\ \text { follow-up } & \text { SF-36, IRQF }\end{array}$

follow-up

SF-36, IRQF compared to preimplantation baseline on

HSCL-25, in 4 of 6 categories of the PQLF and

in 4 of 5 categories of the IRQF

In the SF-36, only 1 of 8 scales showed

significant improvement

These improvements were largest in categories concerning communication, feelings of being a burden, isolation, relations to friends and family, and improvement in relatives' daily lives

\begin{tabular}{ll}
\hline Olze et al., & $\begin{array}{l}n=43(31 \text { female }) \\
2011\end{array}$ \\
implanted at $51.7(16.9)$ \\
years of age
\end{tabular}

Cross-sectional NCIQ

NCIQ

Germany

Significant increase in disease-specific QoL following implantation: mean NCIQ scores increased from 39.3 (15.1) to 60.3 (13.1) Highly significant improvements were observed in all 6 subdomains of the NCIQ

In addition to improvements in hearing, speech understanding, and disease-specific QoL, psychological comorbidity was reduced, and coping strategies were improved following CI surgery

\begin{tabular}{|c|c|c|c|c|c|}
\hline $\begin{array}{l}\text { Rembar et al., } \\
2009\end{array}$ & $\begin{array}{l}n=74 \text { ( } 44 \text { female) } 56.2 \\
\text { (15.2) years of age at time } \\
\text { of study and with } 2.1(1.5) \\
\text { years since CI }\end{array}$ & Cross-sectional & $\begin{array}{l}\text { Ad hoc qualitative } \\
\text { instrument }\end{array}$ & Norway & $\begin{array}{l}\text { Recipients reported that they had received "new } \\
\text { life" with the implant and that their overall } \\
\text { psychological well-being was improved }\end{array}$ \\
\hline $\begin{array}{l}\text { Looi et al., } \\
2011\end{array}$ & $\begin{array}{l}n=94(58 \text { female }) \\
\text { implanted at } 51.9(15.3) \\
\text { years and } 51.5(14.5) \text { years } \\
\text { of age at time of study }\end{array}$ & $\begin{array}{l}\text { Prospective, } \\
\text { longitudinal }\end{array}$ & $\begin{array}{l}\text { Modified NCIQ, } \\
\text { CISQ }\end{array}$ & $\begin{array}{l}\text { New } \\
\text { Zealand }\end{array}$ & $\begin{array}{l}\text { Implanted adults had significantly higher QoL } \\
\text { across all } 6 \text { subdomains of NCIQ than their } \\
\text { nonimplanted hearing-impaired peers on the } \\
\text { waiting list for a CI (mean QoL of } 69.97 \text { and } \\
\text { 41.24, respectively) }\end{array}$ \\
\hline
\end{tabular}


Table 1 (continued)

\begin{tabular}{llll}
\hline Study & $\begin{array}{l}\text { Sample size }(n), \text { gender } \\
(n \text { female), mean age at CI/ } \\
\text { time of study }\end{array}$ & $\begin{array}{l}\text { Primary outcome } \\
\text { metric }\end{array}$ & $\begin{array}{l}\text { Geographic Findings } \\
\text { origin }\end{array}$ \\
\hline
\end{tabular}

\section{Studies in older adults}

Chung et al., $\quad n=283$ (163 female)

$2012 \quad$ implanted at $52.9(15.1)$ years of age
Prospective, SF-36 Canada Significant improvement in QoL was observed longitudinal study before and after impantation across 5 of 8 with 1 year of domains of SF-36 (vitality, physical role follow-up domains of SF-36 (vitality, physical role functioning, and social functioning) Younger implant recipients outperformed older recipients in several domains

\begin{tabular}{llll}
\hline Di Nardo & $n=20(13$ female $)$ & Cross-sectional & SF-36 and \\
et al., & implanted at $67.6(5.5)$ & & Questionnaire for \\
2013 & years and $72.5(5.6)$ years & & Self-Evaluation of CI \\
& of age at time of study & & Benefit with SADL \\
& & scale modification
\end{tabular}

No significant differences were found between the study population and control (younger CI patients) on all subdomains of SF-36 and the Questionnaire for Self-Assessment of CI Benefit However, a significant difference was noted between the 2 populations in overall satisfaction derived from the implant (greater reported satisfaction in the older group)

\begin{tabular}{llll}
\hline Olze et al., & $n=20(10$ female $)$ & Longitudinal & NCIQ, SF-36 \\
2012 & implanted at $74.4(4.6)$ & & Germany \\
& years of age with a mean of & & \\
& $1.8(1.6)$ years since CI &
\end{tabular}

Elderly patients benefited from CI to a higher extent than younger implanted controls on disease-specific quality of life (NCIQ): 31.3 (16.6) to 68.0 (12.4) for the elderly group and 39.7 (14.8) to 61.1 (14.3) for the younger group before and after implantation, respectively Baseline QoL did not differ significantly between elderly and younger controls on SF-36 After CI, the elderly group experienced a significant increase in social functioning and mental health and a significant decrease in physical functioning, and physical component summary subscales of the SF-36

\begin{tabular}{llll}
\hline Orabi et al., & $n=34(15$ female $)$ & Longitudinal & GBI, GHSI
\end{tabular}

Statistically significant improvements after implantation were found in word and sentence recognition scores in quiet and noise, and $82 \%$ of patients were completely satisfied with their cochlear implants

Patients judged that the implantation had restored half the loss of QoL that they had experienced as a result of severe-to-profound deafness, with a highly significant improvement in overall QoL after implantation

\begin{tabular}{lllll}
\hline $\begin{array}{l}\text { Ramos et al., } \\
2013\end{array}$ & $\begin{array}{l}n=26(9 \text { female }) \\
\text { implanted at }>60 \text { years and } \\
69.0(6.6) \text { years of age at } \\
\text { time of study }\end{array}$ & Longitudinal & GBI, SQ & Spain $\begin{array}{l}\text { Patients experienced significant improvement } \\
\text { in their QoL in all areas, especially in general } \\
\text { health, with a smaller improvement in social } \\
\text { interaction } \\
\text { Age, duration of deafness, and years wearing } \\
\text { the process were statistically related to QoL }\end{array}$ \\
$\begin{array}{l}\text { Vermiere } \\
\text { et al., } 2005\end{array}$ & $\begin{array}{l}n=25 \text { (not provided) } \\
\text { implanted at }>70 \text { years }\end{array}$ & Longitudinal & HHIA, GBI & $\begin{array}{l}\text { Belgium } \\
\text { QoL improvement following CI for the elderly } \\
\text { was similar to that of implanted younger adults }\end{array}$
\end{tabular}

AQoL, Assessment of Quality of Life; CCIPP, Children with Cochlear Implants: Parental Perspectives; CES-D, Center for Epidemiologic Studies Depression Scale; CHIP, Child Health and Illness Profile; CIFI, Cochlear Implant Function Index; CISQ, Cochlear Implant Satisfaction Questionnaire (a combination of Satisfaction in Daily Life Questionnaire and Client Satisfaction Questionnaire-8); EQ5D, EuroQoL-5D; GBI, Glasgow Benefit Inventory; GHSI, Glasgow Health Status Inventory questionnaire; HA, hearing aid; HHIA, Hearing Handicap Inventory - Adults; HL, hearing loss; HPS, Hearing Participation Scale; HSCL-25, Hopkins Symptom Check List - 25 items; HUI, Ontario Health Utilities Index; IRQF, Index Relative Questionnaire Form; KINDL ${ }^{\circledR}$, questionnaire for measuring health-related quality of life in children and adolescents including Kiddy (4-7 years), Kid (8-11 years), and Kiddo (12-16 years); NCIQ, Nijmegen Cochlear Implant Questionnaire; NH, normal hearing; PGWB, Psychological General Well-Being index; PQLF, Patient Quality of Life Form; QoL, quality of life; QWB, Quality of Well-Being Scale; SADL, Satisfaction in Daily Life Questionnaire; SLA, Satisfaction with Life Areas Scale; SF-36, Short Form36 questionnaire; SSQ, Speech, Spatial, and Qualities questionnaire; TTO, time trade-off; VAS, visual analog scale; VAS-D, visual analog scale development; YQoL-DHH, Youth Quality of Life - Deaf and Hard of Hearing; SQ, Specific Questionnaire. 
Table 2. Quality of life outcomes following bilateral cochlear implantation

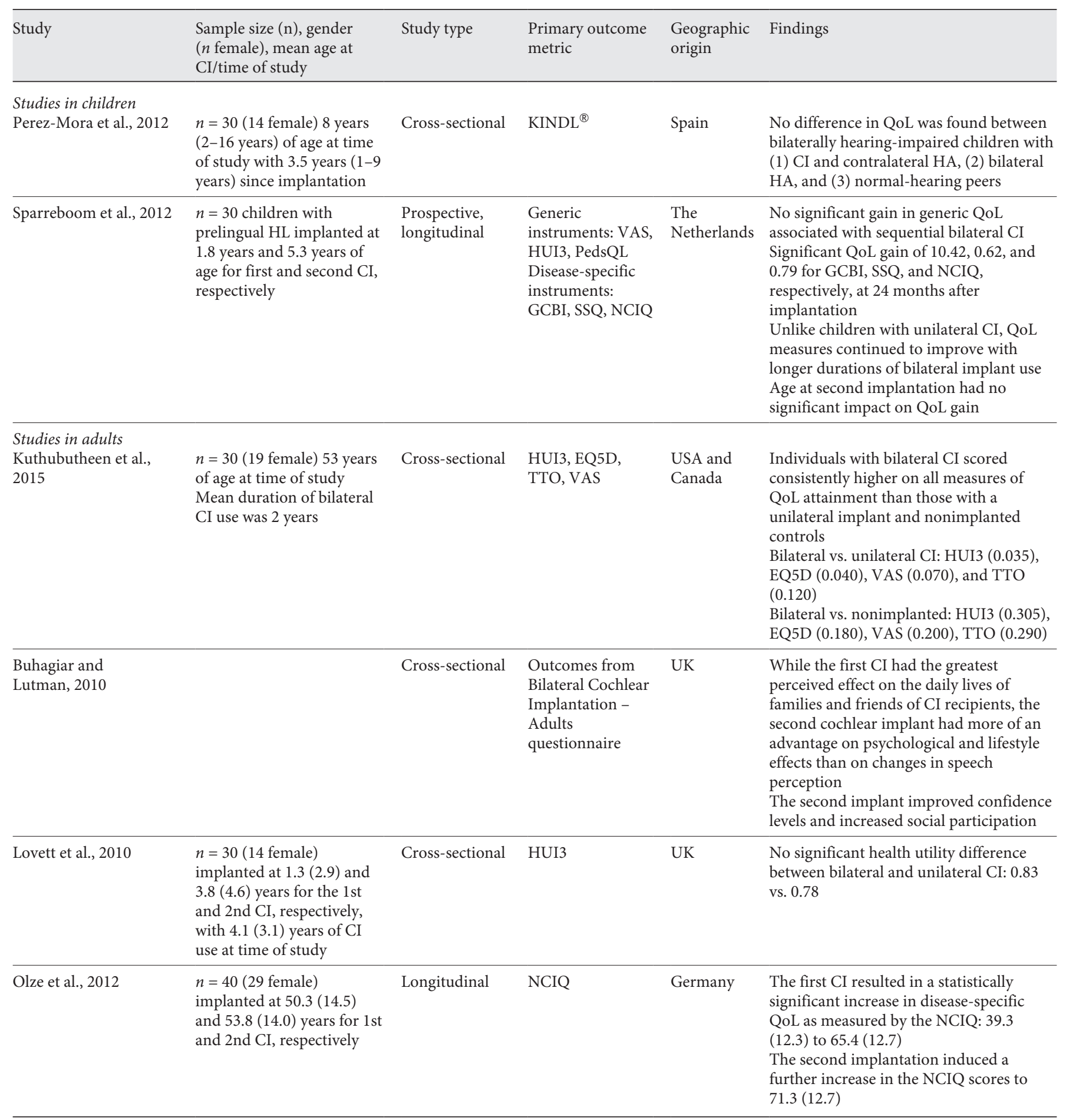

For explanations of abbreviations, see Table 1. 
The CCIPP is a cochlear implant-specific closed-set questionnaire that assesses the following dimensions of a child's experience with the implant: decision to implant, process of implantation, positive effect of the implant, communication, supporting the child, self-reliance, wellbeing and happiness, social relationships, education, and pre- and postoperative services provided by the implant center [O'Neill et al., 2004]. The NCIQ is another CI-specific QoL instrument covering 6 subdomains: basic sound perception, advanced sound perception, speech production, self-esteem, activity and social interactions [Hinderink et al., 2000].

\section{Ad hoc Instruments in Children}

Four articles used ad hoc instruments, which are designed for the purposes of an individual study [Edwards et al., 2012; Schorr et al., 2009; Stacey et al., 2006; WarnerCzyz et al., 2011]. These questionnaires provide considerable information on a child's experience with an implant and use one or a combination of open-ended questionnaires, semistructured interviews, or quantitative instruments. Three studies used quantitative QoL questionnaires [Edwards et al., 2012; Schorr et al., 2009; Stacey et al., 2006; Warner-Czyz et al., 2011] and one used a combination qualitative and quantitative instruments [Schorr et al., 2009]. While providing considerable detail and additional insights that are not often assessed in more established QoL instruments, these questionnaires have not been population validated and are not generalizable across different study groups.

\section{Summary of Results for Children}

Overall, there was no significant difference in QoL attainment between CI recipients and their normal-hearing peers [Clark et al., 2012; Huber, 2005; Meserole et al., 2014; Meyer et al., 2013]. Factors associated with poorer QoL outcomes included use of hearing aids (rather than a CI) [Meyer et al., 2013; Necula et al., 2013], shorter experience with an implant [Loy et al., 2010], older age at implantation [Necula et al., 2013; Schorr et al., 2009; Stacey et al., 2006; Warner-Czyz et al., 2011], additional developmental comorbidities [Sach and Barton, 2007; Edwards et al., 2012], male gender [Sach and Barton, 2007], lower auditory perception [Sach and Barton, 2007], lower parental educational level [Sach and Barton, 2007], and reduced oral communication by the child [FortunatoTavares et al., 2012].

\section{QoL Outcomes in Adults}

Fourteen of the 57 studies focused on presenting metrics for assessing the QoL attainment of adults with cochlear implants. The studies were comprised of participants from 9 countries with a sample size ranging from 8 to 283 study participants. The mean age at implantation ranged from 43 to 67.2 years (Table 1 ).

\section{Generic Instruments in Adults}

Ten studies reported on generic health utility metrics, which included the Short Form-36 (SF-36) [Chung et al., 2012; Damen et al., 2007; Mo et al., 2005], Ontario Health Utilities Index (HUI) Marks II and III [Damen et al., 2007; Faber and Grøntved, 2000; Klop et al., 2007, 2008; Sparreboom et al., 2012], the EQ5D, the VAS from the EQ5D, the time trade-off technique (TTO), the Australian Quality of Life (AQoL) instrument [Hawthorne et al., 2004], the Hopkins Symptom Check List 25 (HSCL-25) [Mo et al., 2005], the Psychological General Well-Being (PGWB) Index [Rembar et al., 2009], and the Glasgow Benefit Inventory (GBI) [Lassaletta et al., 2006]. Although none of these measures are specific to hearing or the effects of CI, some do incorporate hearing ability as part of the measure, as discussed below.

The SF-36 health questionnaire is a generic, validated, 36-item tool developed to evaluate HRQoL of a medical or surgical intervention. The multi-item scale assesses 8 different health domains, including physical functioning, role limitations due to physical problems, social functioning, bodily pain, general mental health, role limitations due to emotional problems, vitality, and general health perceptions [Chung et al., 2012]. The PGWB is a questionnaire that has been used to compare general psychological well-being of CI recipients with the general population. It has also been used to study general psychological well-being in other patient groups treated in audiology practices [Rembar et al., 2012].

The HUI3 is the latest version of the Canadian multiattribute utility instrument. It scores in 8 dimensions, including vision, speech, hearing, ambulation, dexterity, emotion, cognition, and pain. Although a generic instrument, it does include an assessment of the impact of sensory impairments [Kuthubutheen et al., 2015]. The EQ5D and associated VAS are described above. The TTO technique requires subjects to hypothetically trade years of life with normal hearing while maintaining the same health status in other aspects. In one example, subjects were instructed to choose between living in a state of hearing loss for 30 years or forfeiting a portion of the next 30 years beyond their current age for normal hearing 
Table 3. Savings and cost-utility associated with unilateral cochlear implantation

\begin{tabular}{|c|c|c|c|c|}
\hline Study & $\begin{array}{l}\text { Sample size }(n) \text {, } \\
\text { gender ( } n \text { female), } \\
\text { mean age at } \mathrm{CI} / \text { time } \\
\text { of study }\end{array}$ & Primary benefit & Cost analysis & $\begin{array}{l}\text { Geographic } \\
\text { origin }\end{array}$ \\
\hline $\begin{array}{l}\text { Studies in children } \\
\text { Cheng et al., } 2000\end{array}$ & $\begin{array}{l}n=78 \text { (48 female) } 7.5 \\
\text { years of age at time of } \\
\text { study }\end{array}$ & $\begin{array}{l}\text { Statistically significant increases in QoL } \\
\text { before and after CI: } \\
\text { TTO: } 0.75-0.97 \\
\text { VAS: } 0.59-0.86 \\
\text { HUI3: } 0.25-0.64\end{array}$ & $\begin{array}{l}\text { Highly favorable cost-utility ratios: } \\
\text { TTO: USD 9,029 per QALY } \\
\text { VAS: USD 7,500 per QALY } \\
\text { HUI3: USD 5,197 per QALY }\end{array}$ & USA \\
\hline Francis et al., 1999 & $\begin{array}{l}n=35 \text { prelingually } \\
\text { hearing-impaired } \\
\text { children (gender not } \\
\text { provided) implanted } \\
\text { at } 5.2(3.0) \text { years of } \\
\text { age }\end{array}$ & $\begin{array}{l}\text { Children with }>2 \text { years of CI experience were } \\
\text { mainstreamed at greater than twice the rate of } \\
\text { age-matched nonimplanted children with } \\
\text { profound hearing loss and were placed less } \\
\text { frequently in self-contained classrooms, } \\
\text { utilizing fewer hours of special education } \\
\text { support }\end{array}$ & $\begin{array}{l}\text { Pediatric CI results in educational } \\
\text { cost savings ranging from USD 200,000 to } \\
30,000 \text { from kindergarten to } 12 \text { th grade } \\
\text { when compared to school for the deaf and } \\
\text { partial mainstream classroom integration, } \\
\text { respectively }\end{array}$ & USA \\
\hline Koch et al., 1997 & $\begin{array}{l}n=42 \text { between } 4 \text { and } \\
11 \text { years of age at time } \\
\text { of study }\end{array}$ & & $\begin{array}{l}\text { Net present value of CI at a mean age of } \\
4 \text { years, cost of USD 53,098, and average } \\
\text { annual educational cost savings of USD } \\
5,986 \text { was highly favorable at greater than } \\
\text { USD } 40,000\end{array}$ & USA \\
\hline Semenov et al., 2013 & $\begin{array}{l}n=175 \text { children } \\
\text { implanted under } 5 \\
\text { years of age }\end{array}$ & $\begin{array}{l}\text { Statistically significant projected lifetime QoL } \\
\text { (HUI3) gains among CI recipients by age at } \\
\text { implantation: } \\
\text { <18 months: } 10.7 \text { QALYs } \\
\text { 18-36 months: } 9.0 \text { QALYs } \\
\text { >36 months: } 8.4 \text { QALYs }\end{array}$ & $\begin{array}{l}\text { Highly favorable cost-utility ratios with } \\
\text { increasingly favorable ratios at younger } \\
\text { ages: } \\
<18 \text { months: USD } 14,996 \text { per QALY } \\
18 \text { - } 36 \text { months: USD } 17,859 \text { per QALY } \\
\text { >36 months: USD } 19,173 \text { per QALY }\end{array}$ & USA \\
\hline Barton et al., 2003 & $n=199$ & & $\begin{array}{l}\text { Per-child average discounted costs of } \\
\text { CI were: } \\
\text { 1-year horizon: EUR } 42,972 \\
\text { 15-year horizon: EUR } 73,763 \\
73 \text {-year horizon: EUR } 95,034 \\
\text { Cost of maintaining implanted children } \\
\text { was estimated to account for } 22 \% \text { of total } \\
\text { CI expenditures in } 2000 / 2001 \text { and was } \\
\text { predicated to rise to } 63 \% \text { by } 2015 / 2016\end{array}$ & UK \\
\hline Barton et al., 2006a & $n=338$ & & $\begin{array}{l}\text { Mean 2000/2001 annual educational costs: } \\
\text { CI: EUR 28,058 } \\
\text { nonimplanted with moderate HL: } \\
\text { EUR } 15,745 \\
\text { nonimplanted with severe HL: EUR 28,058 }\end{array}$ & UK \\
\hline Barton et al., 2006b & $n=338$ & & $\begin{array}{l}\text { Cumulative economic cost incurred by the } \\
\text { families of implanted children between } \\
\text { implantation and age } 16 \text { years as } \\
\text { compared to families of nonimplanted } \\
\text { children was EUR 3,533 } \\
\text { These costs are } 3 \% \text { of the incremental } \\
\text { health sector costs of implantation }\end{array}$ & UK \\
\hline Barton et al., 2006c & $n=403$ & $\begin{array}{l}\text { QoL (HUI3): a profoundly hearing-impaired } \\
\text { child implanted by } 6 \text { years of age is expected } \\
\text { to gain } 2.23 \text { QALYs over } 15 \text { years after } \\
\text { implantation }\end{array}$ & $\begin{array}{l}\text { Cost of CI: EUR 57,359 } \\
\text { Cost-utility ratio: EUR } 26,629 \text { per QALY } \\
\text { Cost-effectiveness more favorable when } \\
\text { estimated over a child's lifetime rather } \\
\text { than } 15 \text { years, when implanting a child } \\
\text { with greater degree of hearing loss, and } \\
\text { with implantation at younger ages }\end{array}$ & UK \\
\hline
\end{tabular}


Table 3 (continued)

\begin{tabular}{|c|c|c|c|c|}
\hline Study & $\begin{array}{l}\text { Sample size }(n), \\
\text { gender ( } n \text { female), } \\
\text { mean age at } \mathrm{CI} / \text { time } \\
\text { of study }\end{array}$ & Primary benefit & Cost analysis & $\begin{array}{l}\text { Geographic } \\
\text { origin }\end{array}$ \\
\hline O’Neill et al., 2000 & & $\begin{array}{l}\text { CI enables a profoundly hearing-impaired } \\
\text { child to function at the level of a severely } \\
\text { hearing-impaired child using HA with } \\
\text { associated differences and cost-savings in } \\
\text { classroom placement } \\
\text { Estimated annual QoL gain of } 0.23\end{array}$ & $\begin{array}{l}\text { Cost-utility of CI vs. HA: USD } 16,546 \text { per } \\
\text { QALY across a child's projected lifetime }\end{array}$ & UK \\
\hline O’Neill et al., 2001 & & & $\begin{array}{l}\text { Favorable cost-utility ratios: } \\
\text { USD } 12,000-18,000 \text { per QALY }\end{array}$ & UK \\
\hline Sach et al., 2003 & $\begin{array}{l}n=98 \text { ( } 45 \text { female }) \\
\text { implanted at } 5.0 \\
(1.8-15.5) \text { years of } \\
\text { age }\end{array}$ & & $\begin{array}{l}\text { Total cost was negatively related to year of } \\
\text { implant and positively related to number } \\
\text { of hours of rehabilitation } \\
\text { The overall cost-effectiveness improved } \\
\text { over time, suggesting a learning curve in } \\
\text { CI use }\end{array}$ & UK \\
\hline $\begin{array}{l}\text { Schulze-Gattermann } \\
\text { et al., } 2002\end{array}$ & $\begin{array}{l}\text { Pediatric CI recipients } \\
\text { stratified by age at } \\
\text { implantation: } \\
0-1.9 \text { (youngest), } \\
2.2-3.9 \text { (middle), and } \\
3.4-6.9 \text { (oldest) years }\end{array}$ & $\begin{array}{l}\text { Educational savings were used to measure } \\
\text { benefits of CI up to } 16 \text { years of age } \\
\text { (completion of compulsory education) }\end{array}$ & $\begin{array}{l}\text { Total costs: } \\
\text { CI: USD 113,000-152,000 } \\
\text { (youngest to oldest) } \\
\text { HA: USD 138,000 } \\
\text { Age at implantation has significant } \\
\text { implications on the overall favorability of } \\
\text { pediatric CI: children under } 2 \text { years of age } \\
\text { having most favorable cost-benefit ratios } \\
\text { as compared to nonimplanted HA peers }\end{array}$ & Germany \\
\hline
\end{tabular}

Studies in adults

Monteiro et al., $\quad n=637$

2012

CI was significantly associated with an

Canada increase in median yearly income compared to that before implantation (USD 42,672 vs. 30,432), not only improving QoL, but also translating into significant economic benefits for patients and the overall economy, which appear to exceed overall costs of implantation

\begin{tabular}{|c|c|c|c|c|}
\hline $\begin{array}{l}\text { Harris and } \\
\text { Anderson, } 1999\end{array}$ & $\begin{array}{l}n=9 \text { ( } 3 \text { women }), \text { age } \\
\text { range } 23-59 \text { years }\end{array}$ & $\begin{array}{l}\text { The QWB increased } 7.1 \% \text { in } 26 \text { years, } \\
\text { therefore a "well-years" benefit of } 1.85 \\
\text { The estimated well-years benefit was } 0.418 \\
\text { after discounting } 5 \% \text { per year }\end{array}$ & $\begin{array}{l}\text { Cost-benefit/utility ratio can be calculated } \\
\text { to be USD } 22,380-9,125=\text { USD } 13,255 / \\
0.418=\text { USD } 31,711 \text { per well-year }\end{array}$ & USA \\
\hline $\begin{array}{l}\text { Kuthubutheen } \\
\text { et al., } 2015\end{array}$ & $\begin{array}{l}n=30 \text { ( } 16 \text { female) } \\
56 \text { years of age at time } \\
\text { of study. The mean } \\
\text { duration of unilateral } \\
\text { CI use was } 4 \text { years }\end{array}$ & $\begin{array}{l}\text { Statistically significant QoL differences } \\
\text { between unilateral CI vs. no intervention } \\
\text { HUI3: } 0.765 \text { vs. } 0.495 \\
\text { EQ5D: } 0.890 \text { vs. } 0.750 \\
\text { VAS: } 0.810 \text { vs. } 0.680 \\
\text { TTO: } 0.820 \text { vs. } 0.650\end{array}$ & $\begin{array}{l}\text { Highly favorable cost-utility ratios: } \\
\text { HUI3: USD } 9,425 \\
\text { EQ5D: USD } 18,178 \\
\text { VAS: USD } 19,576 \\
\text { TTO: USD } 14,970\end{array}$ & $\begin{array}{l}\text { Canada and } \\
\text { USA }\end{array}$ \\
\hline Palmer et al., 1999 & $\begin{array}{l}n=46(25 \text { female }) \\
\text { implanted at } 54.0 \\
(15.0) \text { years of age }\end{array}$ & $\begin{array}{l}\text { QoL (HUI): } \\
\text { baseline QoL was not statistically different } \\
\text { between CI recipients and nonimplanted HA } \\
\text { controls } \\
\text { CI recipients significantly outperformed } \\
\text { nonimplanted controls at both } 6 \text { months and } \\
12 \text { months afterimplantation attaining health } \\
\text { utility scores of } 0.76(0.18) \text { versus } 0.57(0.18) \\
\text { and } 0.78(0.17) \text { versus } 0.58(0.23) \text {, respectively }\end{array}$ & $\begin{array}{l}\text { Cost-utility ratio: USD } 14,670 \text { per } \\
\text { QALY over a } 22 \text {-year life expectancy } \\
\text { Over } 90 \% \text { of the benefit realized in the first } \\
6 \text { months after implantation }\end{array}$ & USA \\
\hline
\end{tabular}


Table 3 (continued)

\begin{tabular}{|c|c|c|c|c|}
\hline Study & $\begin{array}{l}\text { Sample size }(n), \\
\text { gender ( } n \text { female), } \\
\text { mean age at } \mathrm{CI} / \text { time } \\
\text { of study }\end{array}$ & Primary benefit & Cost analysis & $\begin{array}{l}\text { Geographic } \\
\text { origin }\end{array}$ \\
\hline Wyatt et al., 1996 & $\begin{array}{l}n=229(106 \text { female }) \\
\text { implanted at } 57.1 \\
\text { years of age with a } \\
4.6 \text {-year experience } \\
\text { with CI }\end{array}$ & $\begin{array}{l}\text { QoL (HUI3): } \\
\text { the health utility of the implanted group was } \\
\text { significantly higher than that of their } \\
\text { nonimplanted peers awaiting CI by } 0.204\end{array}$ & $\begin{array}{l}\text { Cost-utility ratio: USD } 15,928 \text { per } \\
\text { QALY with a range from USD } 12,000 \text { to } \\
30,000 \text { per QALY }\end{array}$ & USA \\
\hline $\begin{array}{l}\text { Manrique et al., } \\
2006\end{array}$ & $n=677$ & & $\begin{array}{l}\text { Cost of implantation: postlingual HL } \\
\text { (adult): EUR 36,912-37,048, prelingual } \\
\text { HL (child): EUR 37,689-44,273 }\end{array}$ & Spain \\
\hline $\begin{array}{l}\text { UK Cochlear } \\
\text { Implant Study } \\
\text { Group, } 2004\end{array}$ & $\begin{array}{l}n=311(159 \text { female }) \\
\text { implanted at } 50.8 \\
(49.1-52.5) \text { years of } \\
\text { age }\end{array}$ & QoL measured using HUI3 & $\begin{array}{l}\text { Cost-utility ratio: EUR } 27,142 \\
(24,532 \text { - } 30323) \text { per QALY } \\
\text { Cost-utility varied with age at } \\
\text { implantation: } \\
\text { <30 years: EUR 19,223 per QALY } \\
\text { >70 years: EUR 45,411 per QALY } \\
\text { A greater than } 40 \text {-year duration of } \\
\text { deafness prior to implantation yielded } \\
\text { unfavorable cost-utility ratios given } \\
\text { minimal health utility benefit from } \\
\text { implantation }\end{array}$ & UK \\
\hline $\begin{array}{l}\text { Lee et al., } \\
2006\end{array}$ & $\begin{array}{l}n=11 \text { ( } 4 \text { female) } \\
\text { implanted at } 49.6 \\
(10.9) \text { years of age } \\
\text { with } 5.6(4.8) \text { years of } \\
\text { CI use }\end{array}$ & $\begin{array}{l}\text { QoL pre- and post-CI gain: } \\
\text { VAS: } 0.3(0.3-0.6) \\
\text { HUI: } 0.4(0.3-0.7) \\
\text { EQ5D: } 0.3(0.5-0.8) \\
\text { QWB: } 0.2(0.5-0.7)\end{array}$ & $\begin{array}{l}\text { Cost of CI (discounted): USD } 22,320 \\
\text { Cost-utility ratios: } \\
\text { VAS: USD 19,223 per QALY } \\
\text { HUI: USD 17,387 per QALY } \\
\text { EQ5D: USD 26,064 per QALY } \\
\text { QWB: USD 40,474 per QALY }\end{array}$ & South Korea \\
\hline
\end{tabular}

Studies in older adults

Francis et al., $2002 \quad n=47$ implanted at $63.4(8.6)$ years and 66.5 (8.9) years of age at time of study

\author{
Significant QoL (HUI3) pre- to post-CI gain: \\ overall population: 0.24 \\ postlingual HL: 0.35 \\ prelingual HL: 0.25 (not significant)
}

Cost-utility ratio: USD 9,530 per QALY

USA

\begin{abstract}
AQoL, Assessment of Quality of Life; CCIPP, Children with Cochlear Implants: Parental Perspectives; CHIP, Child Health and Illness Profile; CIFI, Cochlear Implant Function Index; CISQ, Cochlear Implant Satisfaction Questionnaire (a combination of Satisfaction in Daily Life Questionnaire and Client Satisfaction Questionnaire-8); EQ5D, EuroQoL-5D; GBI, Glasgow Benefit Inventory; GHSI, Glasgow Health Status Inventory questionnaire; HA, hearing aid; HHIA, Hearing Handicap Inventory - Adults; HL, hearing loss; HPS, Hearing Participation Scale; HSCL-25, Hopkins Symptom Check List - 25 items; HUI, Ontario Health Utilities Index; IRQF, Index Relative Questionnaire Form; KINDL ${ }^{\circledR}$, questionnaire for measuring health-related quality of life in children and adolescents including Kiddy (4-7 years), Kid (8-11 years), and Kiddo (12-16 years); NCIQ, Nijmegen Cochlear Implant Questionnaire; NH, normal hearing; PGWB, Psychological General Well-Being index; PQLF, Patient Quality of Life Form; QALY, quality-adjusted life years; QoL, quality of life; QWB, Quality of Well-Being Scale; SADL, Satisfaction in Daily Life Questionnaire; SF-36, Short Form-36 questionnaire; SSQ, Speech, Spatial, and Qualities questionnaire; TTO, time trade-off; VAS, visual analog scale; VAS-D, visual analog scale development; YQoL-DHH, Youth Quality of Life - Deaf and Hard of Hearing; SQ, Specific Questionnaire.
\end{abstract}

[Chung et al., 2012]. The TTO is noted to be a difficult task for subjects to complete. Of the 4 instruments HUI3, EQ5D, VAS, and TTO - that have been used in many recent studies, HUI3 is the only tool that measures health utility directly and has been shown to be the most conservative measure of health utility [Chung et al., 2012].

The AQoL measure is a multiattribute utility HRQoL instrument that comprises 5 dimensions measuring ill- ness, social independence, social relationships, sensory abilities, and psychological well-being [Hawthorne et al., 2004]. The HSCL-25 is a self-report, psychological inventory with 58 items, scoring on the 5 underlying dimensions of somatization, obsessive-compulsive, interpersonal sensitivity, anxiety and depression. It has been shown to be a good indicator of emotional distress [Mo et al., 2005]. The GBI is a questionnaire developed to as- 
sess communication abilities and QoL after otolaryngology procedures [Lassaletta et al., 2006]. It has been validated over a wide range of procedures and found to be sensitive to changes in health after the procedure. QoL is measured in 3 domains, social, general, and physical.

\section{Disease-Specific Instruments in Adults}

Nine studies reported on disease-specific QoL instruments in adults, most specific to the benefits of CI. These include the Nijmegen Cochlear Implant Questionnaire (NCIQ) [Cohen et al., 2004; Damen et al., 2007; Fuller et al., 2013; Klop et al., 2007; Looi et al., 2011; Olze et al., 2011 ], the Cochlear Implant Function Index (CIFI) [Fuller et al., 2013], the Speech, Spatial and Qualities Questionnaire (SSQ) [Fuller et al., 2013], Patient Quality of Life Form (PQLF) [Mo et al., 2005], Index Relative Questionnaire Form (IRQF) [Mo et al., 2005], the Hearing Participation Scale (HPS) [Hawthorne et al., 2004], and the Complete Intelligibility Spatiality Quality (CISQ) [Looi et al., 2011].

The NCIQ is a validated, CI-specific HRQoL questionnaire, composed of 3 categories in 6 domains: physical functioning: sound perception - basic, sound perception - advanced, speech production; social functioning: activity, social functioning; and psychological functioning: self-esteem. The CIFI is a tool developed to assess the auditory related function of CI users, in 6 fields of auditory functioning: reliance on visual assistance, telephone use, communication at work, "hearing" in noise, hearing in groups, and hearing in large room settings. The SSQ is a validated environmental and spatial hearing questionnaire that was developed to quantify the abilities of hearing-impaired people and CI users, particularly for speech perception and spatial hearing [Fuller et al., 2013].

The PQLF and IRQF are related instruments, both developed at the House Ear Institute as disease-specific instruments to assess patients' ability to cope with their hearing loss, adaptation to the $\mathrm{CI}$, and emotional alterations since implantation. The PQLF is completed by the hearing-impaired individual, while the IRQF reflects a relative's experience with that individual, including the effect of the hearing handicap on their daily activities, and the hearing-impaired individual's adaptation to the implant [Mo et al., 2005].

The HPS is an 11-item instrument that measures selfesteem, social handicap, and hearing handicap [Hawthorne et al., 2004]. The CISQ was created to enable a rapid and simple instrument to evaluate the benefits of a hearing aid. This 36-item questionnaire assesses an individual's hearing abilities relative to spatiality and quality

Quality of Life and Cost-Utility with

Cochlear Implants of signal, intelligibility in silence, background noise intelligibility, averseness, and reverberation [Looi et al., 2011].

\section{Ad hoc Instruments in Adults}

Four reports included ad hoc QoL instruments [Fuller et al., 2013; Lassaletta et al., 2006; Rembar et al., 2009; Zhao et al., 2008]. Of these, 2 studies used quantitative QoL questionnaires [Fuller et al., 2013; Zhao et al., 2008], 1 used a qualitative instrument [Rembar et al., 2009], and 1 used a combination qualitative and quantitative instrument [Lassaletta et al., 2006].

\section{Summary of Findings for Adults}

Overall, implanted adults showed significant improvement in QoL after implantation [Chung et al., 2012; Hawthorne et al., 2004; Klop et al., 2007, 2008; Mo et al., 2005; Olze et al., 2011; Zhao et al., 2008] and attained significantly higher QoL than their nonimplanted (hearing-aided) peers [Cohen et al., 2004; Looi et al., 2011]. There were no differences in QoL between implanted adults and normal-hearing peers [Rembar et al., 2012]. Most of the QoL benefit of CI was observed within the first 4 months following surgery [Klop et al., 2007, 2008], with the gain sustained for at least 6 years after CI [Damen et al., 2007]. Younger age at implantation was associated with improved QoL outcomes [Chung et al., 2012].

\section{QoL Outcomes in Older Adults}

Six of the 57 studies focused on presenting metrics for assessing the QoL attainment of older adults with cochlear implants. The studies were comprised of participants from 6 countries with a sample size ranging from 20 to 283 study participants. The mean age at implantation ranged from 52.9 to 74.4 years (Table 1 ).

\section{Generic Instruments in Older Adults}

All 6 studies reported on generic health utility metrics, which included the SF-36, GBI, and the Glasgow Health Status Inventory (GHSI) questionnaire. The SF-36 and GBI are described above. The GHSI questionnaire assesses the effect of a hearing problem on overall QoL, including physical health and social support [Orabi et al., 2006].

\section{Disease-Specific Instruments in Older Adults}

Two studies reported on disease-specific QoL instruments in adults, including the Specific Questionnaire (SQ) [Ramos et al., 2013], the NCIQ [Olze et al., 2012], and the Hearing Handicap Inventory - Adults (HHIA) [Vermeire et al., 2005]. The SQ evaluates 6 different aspects related 
Table 4. Savings and cost-effectiveness associated with bilateral cochlear implantation

\begin{tabular}{|c|c|c|c|c|}
\hline Study & $\begin{array}{l}\text { Sample size }(n), \text { age, and } \\
\text { gender of subjects }\end{array}$ & Primary benefit & Cost analysis & $\begin{array}{l}\text { Geographic } \\
\text { origin }\end{array}$ \\
\hline $\begin{array}{l}\text { Studies in children } \\
\text { Foteff et al., } 2016\end{array}$ & $\begin{array}{l}\text { Meta-analysis of Australian } \\
\text { children with bilateral } \\
\text { severe-to-profound SNHL }\end{array}$ & $\begin{array}{l}\text { QoL measure: } \\
\text { HUI3 (literature derived) } \\
\text { Gains of } 0.145 \text { and } 0.208 \text { from bilateral } \\
\text { HAs to unilateral CI and from bilateral } \\
\text { HAs to bilateral CI, respectively } \\
\text { Gain of } 0.063 \text { from unilateral to } \\
\text { bilateral CI }\end{array}$ & $\begin{array}{l}\text { Cost-utility ratios }{ }^{\ddagger} \text { : } \\
\text { unilateral CI vs. bilateral HAs: } \\
\text { USD } 15,335 \\
\text { bilateral CI vs. bilateral HAs: } \\
\text { USD } 27,948 \\
\text { overall CI cohort vs. bilateral HAs: } \\
\text { USD 22,317 }\end{array}$ & Australia \\
\hline Summerfield et al., 2010 & $\begin{array}{l}\text { Opportunity sample of } 180 \\
\text { informants composed of } \\
\text { clinicians, researchers, } \\
\text { students, and parents } \\
\text { valued the QoL of a } \\
\text { hypothetical child born } \\
\text { profoundly deaf }\end{array}$ & $\begin{array}{l}\text { QoL gains using TTO and VAS: } \\
\text { unilateral CI vs. no intervention: } \\
\text { TTO: } 0.11 \\
\text { VAS: } 0.18 \\
\text { unilateral CI with HA vs. no } \\
\text { intervention: } \\
\text { TTO: } 0.16 \\
\text { VAS: } 0.25 \\
\text { bilateral vs. unilateral CI: } \\
\text { TTO: } 0.11 \\
\text { VAS: } 0.13 \\
\text { bilateral CI vs. unilateral CI with HA: } \\
\text { TTO: } 0.05 \\
\text { VAS: } 0.06\end{array}$ & $\begin{array}{l}\text { Cost-utility ratios }{ }^{\ddagger} \text { : } \\
\text { unilateral CI vs. no intervention: } \\
\text { USD } 30,785 \\
\text { bilateral vs. unilateral CI: } \\
\text { USD } 33,740\end{array}$ & UK \\
\hline Bond et al., 2009 & $\begin{array}{l}\text { Meta-analysis of UK } \\
\text { children with prelingual } \\
\text { severe-to-profound SNHL }\end{array}$ & $\begin{array}{l}\text { Lifetime QALYs gained } \\
\text { (literature-derived): } \\
\text { gain of } 4.48 \text { QALYs for unilateral CI } \\
\text { vs. bilateral HAs } \\
\text { gain of } 0.67 \text { QALYs for simultaneous } \\
\text { bilateral vs. unilateral CI } \\
\text { gain of } 0.60 \text { QALYs for sequential } \\
\text { bilateral vs. unilateral CI }\end{array}$ & $\begin{array}{l}\text { Cost-utility ratios }{ }^{\ddagger} \text { : } \\
\text { unilateral CI vs. bilateral HAs: } \\
\text { USD } 20,924 \\
\text { simultaneous bilateral vs. unilateral } \\
\text { CI: USD } 63,040 \\
\text { sequential bilateral vs. unilateral CI: } \\
\text { USD } 84,393\end{array}$ & UK \\
\hline $\begin{array}{l}\text { Studies in adults } \\
\text { Foteff et al., } 2016\end{array}$ & $\begin{array}{l}\text { Meta-analysis of Australian } \\
\text { adults with postlingual } \\
\text { severe-to-profound SNHL, } \\
\text { average age } 55-59 \text { years }\end{array}$ & $\begin{array}{l}\text { QoL measure: } \\
\text { HUI3 (literature derived) } \\
\text { Gains of } 0.145 \text { and } 0.305 \text { from bilateral } \\
\text { HAs to unilateral CI and from bilateral } \\
\text { HAs to bilateral CI, respectively } \\
\text { Gain of } 0.035 \text { from unilateral to } \\
\text { bilateral CI }\end{array}$ & $\begin{array}{l}\text { Cost-utility ratios }{ }^{\ddagger} \text { : } \\
\text { unilateral CI vs. bilateral HAs: } \\
\text { USD } 6,877 \\
\text { bilateral CI vs. bilateral HAs: } \\
\text { USD } 18,785\end{array}$ & Australia \\
\hline Chen et al., 2014 & $n=90$ & $\begin{array}{l}\text { QoL measure: HUI3 } \\
\text { Gains of } 0.270 \text { and } 0.305 \text { from no } \\
\text { intervention to unilateral CI and from } \\
\text { no intervention to bilateral CI, } \\
\text { respectively }\end{array}$ & $\begin{array}{l}\text { Bilateral implantation vs. no } \\
\text { intervention cost of USD } 111,764 \\
\text { yielding an ICUR of USD } 14,658 / \\
\text { QALY } \\
\text { When compared to unilateral CI, } \\
\text { bilateral implantation yielded an } \\
\text { ICUR of USD 55,020/QALY }\end{array}$ & $\begin{array}{l}\text { Canada and } \\
\text { USA }\end{array}$ \\
\hline $\begin{array}{l}\text { Kuthubutheen et al., } \\
2015\end{array}$ & $\begin{array}{l}\text { Bilateral CI: } \\
n=30 \text { ( } 19 \text { female) } 53 \text { years } \\
\text { of age at time of study } \\
\text { The mean duration of } \\
\text { bilateral CI use was } 25 \text { years }\end{array}$ & $\begin{array}{l}\text { QoL measure HUI3, EQ5D, VAS, } \\
\text { TTO: } \\
\text { bilateral vs. no intervention } \\
\text { HUI3: } 0.800 \text { vs. } 0.495 \\
\text { EQ5D: } 0.930 \text { vs. } 0.750 \\
\text { VAS: } 0.880 \text { vs. } 0.680 \\
\text { TTO: } 0.940 \text { vs. } 0.650 \\
\text { bilateral vs. unilateral } \\
\text { HUI3: } 0.800 \text { vs. } 0.795^{\dagger} \\
\text { EQ5D: } 0.930 \text { vs. } 0.890^{\dagger} \\
\text { VAS: } 0.880 \text { vs. } 0.810 \\
\text { TTO: } 0.940 \text { vs. } 0.820\end{array}$ & $\begin{array}{l}\text { Bilateral vs. no intervention ICUR } \\
\text { (per QALY): } \\
\text { HUI3: USD } 14,658 \\
\text { EQ5D: USD } 24,837 \\
\text { VAS: USD 22,353 } \\
\text { TTO: USD } 15,416 \\
\text { bilateral vs. unilateral ICUR } \\
\text { HUI3: USD } 55,020 \\
\text { EQ5D: USD } 48,142 \\
\text { VAS: USD } 27,510 \\
\text { TTO: USD } 16,047\end{array}$ & $\begin{array}{l}\text { Canada and } \\
\text { USA }\end{array}$ \\
\hline
\end{tabular}


Table 4 (continued)

\begin{tabular}{|c|c|c|c|c|}
\hline Study & $\begin{array}{l}\text { Sample size }(n) \text {, age, and } \\
\text { gender of subjects }\end{array}$ & Primary benefit & Cost analysis & $\begin{array}{l}\text { Geographic } \\
\text { origin }\end{array}$ \\
\hline $\begin{array}{l}\text { Bichey and Miyamoto, } \\
2008\end{array}$ & $\begin{array}{l}n=23 \text { participants }(22 \\
\text { female) } 6-79 \text { years of age } \\
\text { at implantation with } 6.3 \\
(0.9-13.6) \text { and } 1.2(0.5- \\
\text { 3.2) years of unilateral and } \\
\text { bilateral CI use, respectively }\end{array}$ & $\begin{array}{l}\text { QoL measured using HUI3 showed } \\
\text { statistically significant differences: } \\
\text { before CI: } 0.33 \\
\text { after unilateral CI: } 0.69 \\
\text { after bilateral CI: } 0.81\end{array}$ & $\begin{array}{l}\text { Bilateral vs. no intervention: } \\
\text { USD 23,345/QALY } \\
\text { Incremental change in cost-utility } \\
\text { from unilateral to bilateral: } \\
\text { USD 2,187/QALY }\end{array}$ & USA \\
\hline Summerfield et al., 2002 & $n=202$ & $\begin{array}{l}\text { QoL measure: HUI2 } \\
\text { More QoL is likely to be gained per } \\
\text { unit of expenditure on unilateral } \\
\text { implantation than on bilateral } \\
\text { implantation }\end{array}$ & $\begin{array}{l}\text { Cost-utility ratios based on } \\
\text { volunteers' estimates: } \\
\text { unilateral implantation versus no } \\
\text { intervention: GBP 16,774 per QALY } \\
\text { unilateral implantation versus } \\
\text { management with HA: GBP 27,401 } \\
\text { per QALY } \\
\text { simultaneous bilateral implantation } \\
\text { versus unilateral implantation: } \\
\text { GBP 61,734 per QALY } \\
\text { provision of an additional implant } \\
\text { versus no additional intervention: } \\
\text { GBP 68,916 per QALY }\end{array}$ & UK \\
\hline $\begin{array}{l}\text { Summerfield and Barton, } \\
2003\end{array}$ & $n=202$ & QoL measure: HUI2 & $\begin{array}{l}\text { Cost-utility ratio: } \\
\text { unilateral CI: GBP } 15542 \text { per QALY } \\
\text { This ratio would be approximately } \\
\text { matched if a bilateral processor cost } \\
10 \% \text { more than a unilateral processor } \\
\text { and if } 2 \text { electrode arrays cost } 10 \% \\
\text { more than } 1\end{array}$ & UK \\
\hline Summerfield et al., 2006 & $n=24$ & $\begin{array}{l}\text { QoL measure: SSQ, GHSI, HUI3, VAS, } \\
\text { EQ5D } \\
\text { A significant negative change in EQ5D } \\
\text { and a positive change in GHSI were } \\
\text { observed before and after the second } \\
\text { implantation } \\
\text { Spatial hearing (SSQ) also showed a } \\
\text { significant positive change } \\
\text { None of the other changes were } \\
\text { significant } \\
\text { Overall, there was a minimal impact of } \\
\text { health utility of } 0.03\end{array}$ & $\begin{array}{l}\text { Cost-utility ratio of second CI: } \\
\text { EUR 102,500 per QALY } \\
\text { Increasing CI effectiveness through } \\
\text { enhanced signal processing in } \\
\text { binaural processors and reducing the } \\
\text { cost of implant hardware may make } \\
\text { the cost-utility of a second implant } \\
\text { more favorable }\end{array}$ & UK \\
\hline
\end{tabular}

AQoL, Assessment of Quality of Life; CCIPP, Children with Cochlear Implants: Parental Perspectives; CHIP, Child Health and Illness Profile; CIFI, Cochlear Implant Function Index; CISQ, Cochlear Implant Satisfaction Questionnaire (a combination of Satisfaction in Daily Life Questionnaire and Client Satisfaction Questionnaire-8); EQ5D, EuroQoL-5D; GBI, Glasgow Benefit Inventory; GHSI, Glasgow Health Status Inventory questionnaire; HA, hearing aid; HHIA, Hearing Handicap Inventory - Adults; HL, hearing loss; HPS, Hearing Participation Scale; HSCL-25, Hopkins Symptom Check List, 25 items; HUI, Ontario Health Utilities Index; ICUR, incremental cost-utility ratio; IRQF, Index Relative Questionnaire Form; KINDL ${ }^{\circledR}$, questionnaire for measuring health-related quality of life in children and adolescents including Kiddy (4-7 years), Kid (8-11 years), and Kiddo (12-16 years); NCIQ, Nijmegen Cochlear Implant Questionnaire; NH, normal hearing; PGWB, Psychological General Well-Being index; PQLF, Patient Quality of Life Form; QALY, qualityadjusted life years; QoL, quality of life; QWB, Quality of Well-Being Scale; SADL, Satisfaction in Daily Life Questionnaire; SF-36, Short Form-36 questionnaire; SNHL, sensorineural hearing loss; SSQ, Speech, Spatial, and Qualities questionnaire; TTO, time trade-off; VAS, visual analog scale; VAS-D, visual analog scale development; YQoL-DHH, Youth Quality of Life - Deaf and Hard of Hearing; SQ, Specific Questionnaire. ${ }^{\dagger}$ Not statistically significant. ${ }^{\ddagger}$ Converted to USD using yearly average exchange rates provided from http://www.usforex.com/forex-tools/historical-rate-tools/yearly-average-rates based on year study was published.

to CI: speech recognition, social interaction, telephone use, confidence, family life, and satisfaction [Faber and Grøntved, 2000; Ramos et al., 2013]. The NCIQ is described above. The HHIA is a well-validated question- naire that assesses hearing handicap in adult populations. The HHIA is a 25-item, hearing-specific, QoL scale with 2 components that measure the emotional and situational impact of hearing loss [Vermeire et al., 2005]. 


\section{Ad hoc Instruments in Older Adults}

Four reports included ad hoc QoL instruments [Di Nardo et al., 2014; Olze et al., 2012; Orabi et al., 2006; Vermeire et al., 2005]. Of these, 3 studies used quantitative QoL questionnaires, and 1 [Olze et al., 2012] used a qualitative instrument.

\section{Summary of Results for Older Adults}

Overall, implanted older adults showed significant improvement in QoL after implantation [Chung et al., 2012; Di Nardo et al., 2014; Olze et al., 2012; Orabi et al., 2006; Ramos et al., 2013; Vermeire et al., 2005]. Improvements in QoL were independent of audiological performance. While all studies demonstrated significant auditory benefit of CI in all age groups, some studies [Di Nardo et al., 2014; Ramos et al., 2013; Vermeire et al., 2005] showed poorer auditory performance in the elderly group, and others showed a similar benefit of CI regardless of age [Olze et al., 2012; Orabi et al., 2006]. Regardless, nearly all studies showed significant improvement in QoL in this age group, most often reported in multiple dimensions.

\section{Discussion}

The objective of this narrative review was to comprehensively assess the literature on the QoL determination and attainment among CI recipients of all ages, and to examine cost-effectiveness measures. We were able to access a large compendium of research conducted over the past 2 decades and around the world to assess the impact of CI in deafness from a perspective that combines economic considerations with measured outcome of implantation offered by recipients or proxies. We observed a consistently high impact of implantation on perceived QoL, and a general trend towards favorable economic impact of CI that is subject to single- versus bilateralimplantation considerations.

Studies that combine clinical and economic evaluation are increasingly important in guiding comprehensive assessments and payer decision-making. Such decisionmaking is critical to the acceptance of new technologies; however, there is often limited, timely evidence available to payers on the effectiveness and cost-effectiveness of emerging and evolving technologies [Steiner et al., 1996]. As a result, health care stakeholders are at a disadvantage when attempting to justify interventions based not only on safety and efficacy, but also on cost-effectiveness. Economic analyses, when based on a broad range of HRQoL domains that permit comparison of outcomes across interventions, diseases, and populations, can provide guidance in programmatic initiatives designed to enhance performance and contain costs while prioritizing expenditures.

The results of this review suggest that an approach to the question "Are cochlear implants cost-effective?" is nuanced and that a meaningful answer must incorporate multiple factors that offer objective measures and reflect priorities of hearing-impaired individuals, professionals with relevant expertise, and society in general. We observed that even when priorities are recognized, the answer varies, depending on the economic measures used in the analysis.

\section{Economic Evaluation Measures}

Changes in quality-adjusted life years that are based on HRQoL measures can vary based on several factors, including the measurement tool used (whether direct or indirect measure, disease-specific or generic measurement), and the population studied (e.g., whether those surveyed are hearing-impaired CI candidates, individuals with unilateral or bilateral implants, hearing health care professionals, parents serving as proxy respondents for their children, or members of society). We noted consistency across studies using the various instruments; however, the HUI3 is generally regarded as the most conservative and consistent measure of HRQoL for studies of CI cost utility [Kuthubutheen et al., 2015]. In most studies, the HUI3 does not show significant gain in utility from the unilateral to bilateral CI condition though it was reported clearly sensitive to unilateral CI. For this reason, the costutility analysis of bilateral intervention is highly driven by the increase in cost (up to double the cost of unilateral CI) with modest commensurate, enhanced utility produced by bilateral implantation.

CI analysts have struggled to understand why the impact of a technology that patients consistently value as a life-changing intervention, such as bilateral CI, is not reflected in significant increments in utility scores. It is possible that the communicative advantages produced are simply not captured in the instruments used, and even disease-specific metrics often fail to capture the nuanced ways in which access to binaural auditory inputs may confer enhanced connectivity. We noted that part of the challenge is adequately probing the benefit of a second implant when a first implant has been placed. Weighted-average QoL gains, reflected in generic QoL instruments, were observed in our literature survey to be 0.04 in children and 0.08 in adults (Ta- 
Table 5. Weighted average of observed quality of life changes after cochlear implantation comparing unilateral and bilateral implantation with no intervention and bilateral implantation with unilateral implantation

\begin{tabular}{|c|c|c|c|c|c|c|}
\hline \multirow{3}{*}{$\begin{array}{l}\text { QoL instrument } \\
\text { type }\end{array}$} & \multicolumn{6}{|c|}{ Weighted-average QoL gain ${ }^{\dagger}$} \\
\hline & \multicolumn{2}{|c|}{ unilateral vs. no intervention } & \multicolumn{2}{|c|}{ bilateral vs. no intervention } & \multicolumn{2}{|l|}{ bilateral vs. unilateral } \\
\hline & absolute gain (range) & percent gain (range) & absolute gain (range) & percent gain (range) & absolute gain (range) & percent gain (range) \\
\hline \multicolumn{7}{|l|}{ Children } \\
\hline Generic & $0.27(0.03-0.45)$ & $93.4(3.2-156)$ & $0.26(0.21-0.31)$ & 90.4 (na) & $0.04(0.03-0.06)$ & $16.9(13-29.2)$ \\
\hline Disease specific & 0.09 (na) & $18.8(\mathrm{na})$ & na & na & $0.1(0.05-0.14)$ & na \\
\hline Disease specific & $0.28(0.2-0.5)$ & $89.1(41.7-312.5)$ & 0.62 (na) & 476.9 (na) & $0.1(0.06-0.15)$ & $15.9(9-23.1)$ \\
\hline
\end{tabular}

This represents the weighted-average QoL gain by intervention based on the data shown in the previous tables. Gains are significant regardless of the instrument used (generic vs. disease specific) whether comparing unilateral or bilateral CI with no intervention. However, gains achieved by bilateral versus unilateral CI are modest. There is a modest tendency toward disease-specific instruments being more sensitive to the benefits of bilateral implantation. ${ }^{\dagger}$ Using the quality of life gain and sample size of the studies reported in Tables $1-4$.

ble 5). These same weighted-average QoL gains are, when considered in the context of bilateral implantation as compared with the baseline state, 0.26 for children and 0.24 for adults - gains in utility that are substantial in comparison to many established medical and surgical interventions.

The neurobiology of the central auditory system informs us that the system relies on bilateral stimulation to develop normal optimal function. While significant gains in localization and the ability to understand speech in the presence of background noise are realized in bilateral CI recipients [Kral and O'Donoghue, 2010], such benefits are not robust by current QoL measures. It must be appraised whether this discrepancy is a failure of CI to adequately restore an important sensory deficit, or whether current measurement tools are simply inadequate to demonstrate a meaningful gain in function. When QoL gains are modest, costs of the intervention become more important. For this reason, efforts to control incremental costs of bilateral CI, which are limited primarily to the cost of the second implant and the episode of care, are of great importance.

Sensitivity analyses are particularly useful to describe the variety of costs and other assumptions that drive the determination of cost-utility analysis. Costs can vary widely both within and between countries, and aggressive cost-cutting measures can improve financial sustainability [McKinnon, 2014]. Factors that can be examined in sensitivity analyses may include: numbers of preand post-CI assessments, failure rates of external devices out of warranty, discount rates (for costs as well as ben-

Quality of Life and Cost-Utility with

Cochlear Implants efits over time), time horizon, utility gains, timing of surgeries such as bilateral sequential and simultaneous implants, and time horizon of the intervention. Cost-utility of bilateral versus unilateral CI is highly dependent upon cost of the second implant. In some health care settings, the cost of the second implant, particularly if placed simultaneously, has been discounted 50\% from the first device.

While HRQoL is traditionally used in economic analyses, there are other measures of outcome that can be considered and have not been typically measured in cost-utility analyses of CI. These measures reflect financial wellbeing and contributions to society by the hearing-impaired individual. Work by Emmett and Francis [2014] using the US National Health and Nutrition Examination Survey information from 1999 to 2002 demonstrated that individuals with hearing loss (World Health Organization definition of bilateral pure-tone average of $0.5,1,2$, and 4 $\mathrm{kHz}$ of greater than $25 \mathrm{~dB}$ ) were 3.21 times more likely to have low educational attainment (not complete high school), 1.58 times more likely to be of low income (family income less than USD 20,000 per annum), and 1.98 times more likely to be unemployed or underemployed (work less than $35 \mathrm{~h}$ per week). Other societal benefits may include lower rates of depression and dementia in elderly CI recipients. It is not yet clear if individuals with hearing loss and CI perform as well as normal-hearing people with respect to these important measures of health, well-being, and contributions to society, but several studies do suggest that income levels for adults are improved following CI and that eventual educational and employ- 
Table 6. Summary of cost-utility ratios (USD) by age groupings across studies

\begin{tabular}{|c|c|c|c|c|c|c|}
\hline Study & Year & TTO & VAS & HUI & EQ5D & QWB \\
\hline \multicolumn{7}{|l|}{ Unilateral CI versus no intervention } \\
\hline \multicolumn{7}{|l|}{ Studies in children } \\
\hline Cheng et al., 2000 & 2000 & 9,029 & 7,500 & 5,197 & & \\
\hline O’Neill et al., 2000 & 2000 & & & 16,546 & & \\
\hline O’Neill et al., 2001 & 2001 & & & 15,000 & & \\
\hline Barton et al., 2003 & 2006 & & & 34,617 & & \\
\hline Semenov et al., $2013^{\ddagger}$ & 2013 & & & 17,085 & & \\
\hline Mean & & 9,029 & 7,500 & 17,689 & & \\
\hline \multicolumn{7}{|l|}{ Studies in adults } \\
\hline Wyatt et al., 1996 & 1996 & & & 15,928 & & \\
\hline Palmer et al., 1999 & 1999 & & & 14,670 & & \\
\hline \multicolumn{7}{|l|}{ UK Cochlear Implant } \\
\hline Study Group, 2004 & 2004 & & & 35,284 & & \\
\hline Lee et al., 2006 & 2006 & & 19,223 & 17,387 & 26,064 & 40,474 \\
\hline Kuthubutheen et al., 2015 & 2015 & 14,970 & 19,756 & 9,425 & 18,178 & \\
\hline Summerfield et al., $2002^{\dagger}$ & 2002 & & & 43,842 & & \\
\hline Summerfield and Barton, $2003^{\dagger}$ & 2003 & & & 24,867 & & \\
\hline Harris and Anderson & 1999 & & & & & 31,711 \\
\hline Mean & & 14,970 & 19,490 & 23,058 & 22,121 & 40,474 \\
\hline \multicolumn{7}{|l|}{ Studies in older adults } \\
\hline Francis et al., 2002 & 2002 & & & 9,530 & & \\
\hline Mean & & & & 9,530 & & \\
\hline \multicolumn{7}{|l|}{ Bilateral CI versus no intervention } \\
\hline \multicolumn{7}{|l|}{ Studies in children } \\
\hline Bond et al., 2009 & 2009 & & & 29,519 & & \\
\hline Summerfield et al., 2010 & 2010 & 34,824 & 23,026 & & & \\
\hline Mean & & 34,824 & 23,026 & 29,519 & & \\
\hline \multicolumn{7}{|l|}{ Studies in adults } \\
\hline Bichey and Miyamoto, 2008 & 2008 & & & 23,345 & & \\
\hline Bond et al., 2009 & 2009 & & & 33,132 & & \\
\hline Chen et al., 2014 & 2014 & & & 14,658 & & \\
\hline Kuthubutheen et al., 2015 & 2015 & 22,353 & 15,416 & 14,658 & 24,837 & \\
\hline Mean & & 22,353 & 15,416 & 21,448 & 24,837 & \\
\hline \multicolumn{7}{|l|}{ Bilateral CI versus unilateral CI } \\
\hline \multicolumn{7}{|l|}{ Studies in children } \\
\hline Bond et al., 2009 & 2009 & & & 70,470 & & \\
\hline Summerfield et al., 2010 & 2010 & 37,100 & 30,973 & & & \\
\hline Mean & & 37,100 & 30,973 & 70,470 & & \\
\hline \multicolumn{7}{|l|}{ Studies in adults } \\
\hline Bichey and Miyamoto, $2008^{\ddagger}$ & 2008 & & & 38,652 & & \\
\hline Bond et al., 2009 & 2009 & & & 86,425 & & \\
\hline Kuthubutheen et al., 2015 & 2015 & 27,510 & 16,047 & 55,020 & 48,142 & \\
\hline Mean & & 27,510 & 16,047 & 60,032 & 48,142 & \\
\hline
\end{tabular}

This table demonstrates that, for studies performed in most developed countries, cost-utility ratios are well below the threshold of USD 50,000. The exception to this standard is in the UK studies, which demonstrate costs substantially higher than in other parts of the developed world (e.g., Summerfield and Bond studies and NICE report). The reason for this discrepancy in cost-utility is not apparent from a reading of the literature and should be examined more deliberately in the future. TTO, time trade-off; VAS, visual analog scale; HUI, Health Utilities Index; EQ5D, EuroQoL-5D; QWB, Quality of Well-Being Scale.

${ }^{\dagger}$ Using USD exchange rates for the year the study was published. ${ }^{\ddagger}$ Median value calculated by authors. 
ment attainment for children with CI may be on par with those with normal hearing [McKinnon, 2014]. Hence, as difficult as it is to define all possible costs of an intervention, it is equally challenging to fully reflect all possible associated benefits to society. These benefits can be, but have not yet been, measured in financial terms.

The final step in the economic analysis requires that incremental cost-utility be determined to reflect the incremental cost per HRQoL benefit from CI. Thresholds are set based on the incremental cost-utility ratio: if it falls below this set level, an intervention is determined to be "cost-effective." This varies by country in the developed world. This threshold is approximately USD 50,000 in the USA, and an equivalent-currency cost in the UK. Here, we observed that despite variance in utility associated with different methodologies, the calculated cost-utility ratios for the USA and Canada consistently met this threshold, indicating high value for expenditures on CI (Table 6). Some of the studies, particularly those performed in the UK, revealed higher cost-utility ratios; the reason for this is not known, but should be explored further. Such data can also be assessed in developing countries, wherein the threshold for cost-effectiveness suggested by the World Health Organization as a factor of gross domestic product can be developed using a methodology that drives CI feasibility in lower income countries [Emmett et al., 2015].

\section{Range of Outcomes Observed (Unilateral)}

Results observed in this survey demonstrated mean health-utility gains in children receiving unilateral implants ranging on average from 0.27 with generic measures to 0.09 with disease-specific measures (single study). In adults, utility gains in generic QoL measures ranged on average from 0.21 with generic measures to 0.28 with disease-specific measures. While there is variability in these pooled results, mean gains in utility that were observed to consistently exceed 0.20 are impressive and rarely observed in health utility studies of interventions commonly covered, for example, within the US health care system.

\section{Range of Outcomes (Bilateral)}

Health utility gains following bilateral CI may be compared either to no intervention, in which case gains are robust (average 0.26 and 0.24 using generic measures for children and adults, respectively, and 0.62 using diseasespecific measures for adults), or to unilateral implantation, in which case benefits, as mentioned previously, are more nuanced. Absolute gains in health utility for 2 versus $1 \mathrm{CI}$ average from 0.04 to 0.1 in children for generic versus disease-specific measures, and from 0.08 to 0.1 in adults for the same. In each case, there is a small tendency for the disease-specific measures to be more reflective of the benefits of bilateral CI. This makes sense, as bilateral CI is less likely to show incremental benefits in overall QoL than to benefit the individual in listening in complex auditory environments, particularly with adequate time for follow-up and refinement of auditory skills.

\section{Overall Valuation and Related Ethical Considerations}

The overall economic value of CI is generally regarded as greater in children who are implanted early in life than in adults, both because of the greater benefit over longer mean time horizons, and because of the fact that young children with significant hearing loss do not develop normal speech and language skills. This raises an ethical consideration: What if lack of spoken language is considered acceptable, "normal" and even desirable for a segment of the population? For example, this is the often discussed case with a deaf community stance. How should their valuation of utility of intervention for deafness, which they do not regard as a disability, be considered? We note that this situation is quite different from the stroke victim for whom health care providers are considering a costly intervention, or for a potential transplant recipient. One argument is that, while a dialogue around issues related to health valuation can include a choice of perspective (patients or ablebodied individuals) as well as the perimeter of assessment (medical or nonmedical care), the community finance of treatment such as bilateral CI for children is justified once it is shown that the disability has a significant impact on the fundamental social achievements of the individual and that such treatment can reduce inequalities effectively [Thebaut, 2013]. Evidence of the first point has been advanced [Emmett and Francis, 2014], and evidence of the second point continues to accumulate.

\section{Conclusions}

Considerable work has been done on the QoL attainment and health economic implications of CI. Unilateral CI across all age groups leads to reported sustained benefits in the recipients' overall and disease-specific QoL. With increased cost associated with bilateral CI, further study is needed to characterize its costs and benefits with respect to the recipients' health, well-being, and contributions to society. 


\section{Disclosure Statement}

There was no conflict of interest.

\section{Funding Sources}

There was no funding/support.

\section{References}

Barton GR, Bloor KE, Marshall DH, Summerfield AQ: Health-service costs of pediatric cochlear implantation: multi-center analysis. Int $\mathrm{J} \mathrm{Pe}$ diatr Otorhinolaryngol 2003;672:141-149.

Barton GR, Stacey PC, Fortnum HM, Summerfield AQ: Hearing-impaired children in the United Kingdom, II: cochlear implantation and the cost of compulsory education. Ear Hear 2006a;27:187-207.

Barton GR, Fortnum HM, Stacey PC, Summerfield AQ: Hearing-impaired children in the United Kingdom, III: cochlear implantation and the economic costs incurred by families. Ear Hear 2006b;27:563-574.

Barton GR, Stacey PC, Fortnum HM, Summerfield AQ: Hearing-impaired children in the United Kingdom, IV: cost-effectiveness of pediatric cochlear implantation. Ear Hear 2006c;27:575-588.

Bichey BG, Miyamoto RT: Outcomes in bilateral cochlear implantation. Otolaryngol Head Neck Surg 2008;138:655-661.

Bond M, Mealing S, Anderson R, et al: The effectiveness and cost-effectiveness of cochlear implants for severe to profound deafness in children and adults: a systematic review and economic model. Health Technol Assess 2009;13:1-330.

Buhagiar R, Lutman M: Quality of life measures for patients with bilateral cochlear implants. Cochlear Implants Int 2010;11(Suppl 1):264267.

Chen JM, Amoodi H, Mittmann N: Cost-utility analysis of bilateral cochlear implantation in adults: a health economic assessment from the perspective of a publicly funded program. Laryngoscope 2014;124:1452-1458.

Cheng AK, Rubin HR, Powe NR, Mellon NK, Francis HW, Niparko JK: Cost-utility analysis of the cochlear implant in children. JAMA 2000;284:850-856.

Chung J, Chueng K, Shipp D, Friesen L, Chen JM, Nedzelski JM, Lin VY: Unilateral multi-channel cochlear implantation results in significant improvement in quality of life. Otol Neurotol 2012;33:566-571.

Clark JH, Wang NY, Riley AW, Carson CM, Meserole RL, Lin FR, Eisenberg LS, Tobey EA, Quittner AL, Francis HW, Team CDI, Niparko JK: Timing of cochlear implantation and parents' global ratings of children's health and development. Otol Neurotol 2012;33:545552.

Cohen SM, Labadie RF, Dietrich MS, Haynes DS: Quality of life in hearing-impaired adults: the role of cochlear implants and hearing aids. Otolaryngol Head Neck Surg 2004;131:413422.
Damen GW, Beynon AJ, Krabbe PF, Mulder JJ, Mylanus EA: Cochlear implantation and quality of life in postlingually deaf adults: long-term follow-up. Otolaryngol Head Neck Surg 2007;136:597-604.

Di Nardo W, Anzivino R, Giannantonio S, Schinaia L, Paludetti G: The effects of cochlear implantation on quality of life in the elderly. Eur Arch Otorhinolaryngol 2014;271:65-73.

Edwards L, Hill T, Mahon M: Quality of life in children and adolescents with cochlear implants and additional needs. Int J Pediatr Otorhinolaryngol 2012;76:851-857.

Emmett SD, Francis HW: Bilateral hearing loss is associated with decreased nonverbal intelligence in US children aged 6-16 years. Laryngoscope 2014; 124:2176-2181.

Emmett SD, Francis HW: The socioeconomic impact of hearing loss in US adults. Otol Neurotol 2015;36:545-550.

Emmett SD, Tucci DL, Smith M, Macharia IM, Ndegwa SN, Nakku D, Mukara KB, Ibekwe TS, Mulwafu W, Gong W, Francis HW, Saunders JE: GDP matters: cost effectiveness of cochlear implantation and deaf education in sub-Saharan Africa. Otol Neurotol 2015;36: 1357-1365.

Faber CE, Grøntved AM: Cochlear implantation and change in quality of life. Acta Otolaryngol 2000;120:151-153.

Fortunato-Tavares T, Befi-Lopes D, Bento RF, De Andrade CRF: Children with cochlear implants: communication skills and quality of life. Braz J Otorhinolaryngol 2012;78:15-25.

Foteff C, Kennedy S, Milton AH, Deger M, Payk F, Sanderson G: Cost-utility analysis of cochlear implantation in Australian adults. Otol Neurotol 2016;37:454-461.

Francis HW, Koch ME, Wyatt JR, Niparko JK: Trends in educational placement and costbenefit considerations in children with cochlear implants. Arch Otolaryngol Head Neck Surg 1999;125:499-505.

Francis HW, Chee N, Yeagle J, Cheng A, Niparko JK: Impact of cochlear implants on the functional health status of older adults. Laryngoscope 2002;112(8 Pt 1):1482-1488.

Froberg DG, Kane RL: Methodology for measuring health-state preferences. II. Scaling methods. J Clin Epidemiol 1989;42:459-471.

Fuller C, Mallinckrodt L, Maat B, Baskent D, Free $\mathrm{R}$ : Music and quality of life in early-deafened late-implanted adult cochlear implant users. Otol Neurotol 2013;34:1041-1047.
Gusi N, Olivares PR, Rajendram R: The EQ-5D Health-Related Quality of Life Questionnaire; in Preedy VR, Watson RR (eds): Handbook of Disease Burdens and Quality of Life Measures. New York, Springer, 2010.

Harris JP, Anderson JP: An outcomes study of cochlear implants in deaf patients. Otolaryngol Head Neck Surg 1999;121:675-676.

Hawthorne G, Hogan A, Giles E, Stewart M, Kethel L, White K, Plaith B, Pedley K, Rushbrooke E, Taylor A: Evaluating the healthrelated quality of life effects of cochlear implants: a prospective study of an adult cochlear implant program. Int J Audiol 2004;43: 183-192.

Hinderink JB, Krabbe PF, Van Den Broek P: Development and application of a health-related quality-of-life instrument for adults with cochlear implants: the Nijmegen Cochlear Implant Questionnaire. Otolaryngol Head Neck Surg 2000;123:756-765.

Huber M: Health-related quality of life of Austrian children and adolescents with cochlear implants. Int J Pediatr Otorhinolaryngol 2005;69:1089-1101.

Huttunen K, Rimmanen S, Vikman S, Virokannas N, Sorri M, Archbold S, Lutman ME: Parents' views on the quality of life of their children 2-3 years after cochlear implantation. Int J Pediatr Otorhinolaryngol 2009;73:17861794.

Klop WM, Boermans PP, Ferrier MB, Van Den Hout WB, Stiggelbout AM, Frijns JH: Clinical relevance of quality of life outcome in cochlear implantation in postlingually deafened adults. Otol Neurotol 2008;29:615-621.

Klop WM, Briaire JJ, Stiggelbout AM, Frijns JH: Cochlear implant outcomes and quality of life in adults with prelingual deafness. Laryngoscope 2007;117:1982-1987.

Kobau R, Sniezek J, Zack MM, Lucas RE, Burns A: Well-being assessment: an evaluation of well-being scales for public health and population estimates of well-being among US adults. Appl Psychol Health Well-Being 2010; 2:272-297.

Koch ME, Wyatt JR, Francis HW, Niparko JK: A model of educational resource use by children with cochlear implants. Otolaryngol Head Neck Surg 1997;117(3 Pt 1):174-179.

Kral A, O'Donoghue GM: Profound deafness in childhood. N Engl J Med 2010;363:14381450.

Kuthubutheen J, Mittmann N, Amoodi H, Qian W, Chen JM: The effect of different utility measures on the cost-effectiveness of bilateral cochlear implantation. Laryngoscope 2015; 125:442-447. 
Lassaletta L, Castro A, Bastarrica M, De Sarria MJ, Gavilan J: Quality of life in postlingually deaf patients following cochlear implantation. Eur Arch Otorhinolaryngol 2006;263:267-270.

Lee H-Y, Park E-C, Kim HJ, Choi J-Y, Kim H-N: Cost-utility analysis of cochlear implants in Korea using different measures of utility. Acta Otolaryngol 2006;126:817-823.

Lindemark F, Norheim OF, Johansson KA: Making use of equity sensitive QALYs: a case study on identifying the worse off across diseases. Cost Eff Resour Alloc 2014;12:16.

Looi V, Mackenzie M, Bird P, Lawrenson R: Quality-of-life outcomes for adult cochlear implant recipients in New Zealand. NZ Med J 2011;124:21-34.

Lovett RES, Kitterick PT, Hewitt CE, Summerfield AQ: Bilateral or unilateral cochlear implantation for deaf children: an observational study. Arch Dis Child 2010;95:107-112.

Loy B, Warner-Czyz AD, Tong L, Tobey EA, Roland PS: The children speak: an examination of the quality of life of pediatric cochlear implant users. Otolaryngol Head Neck Surg 2010;142:247-253.

Manrique M, Ramos A, Morera C, et al: Analysis of the cochlear implant as a treatment technique for profound hearing loss in pre and postlocutive patients (in Spanish). Acta Otorrinolaringol Esp 2006;57:2-23.

McKinnon BJ: Cost effectiveness of cochlear implants. Curr Opin Otolaryngol Head Neck Surg 2014;22:344-348.

Meserole RL, Carson CM, Riley AW, Wang NY, Quittner AL, Eisenberg LS, Tobey EA, Francis HW, Niparko JK: Assessment of health-related quality of life 6 years after childhood cochlear implantation. Qual Life Res 2014;23: 719-731.

Meyer A, Sie K, Skalicky A, Edwards TC, Schick B, Niparko J, Patrick DL: Quality of life in youth with severe to profound sensorineural hearing loss. JAMA Otolaryngol Head Neck Surg 2013;139:294-300.

Mo B, Lindbaek M, Harris S: Cochlear implants and quality of life: a prospective study. Ear Hear 2005;26:186-194.

Monteiro E, Shipp D, Chen J, Nedzelski J, Lin V: Cochlear implantation: a personal and societal economic perspective examining the effects of cochlear implantation on personal income. J Otolaryngol Head Neck Surg 2012; 41(Suppl 1):S43-S48.

Necula V, Cosgarea M, Necula SE: Health-related quality of life in cochlear implanted patients in Romania. Int J Pediatr Otorhinolaryngol 2013;77:216-222.

Olze H, Gräbel S, Förster U, Zirke N, Huhnd LE, Haupt H, Mazurek B: Elderly patients benefit from cochlear implantation regarding auditory rehabilitation, quality of life, tinnitus, and stress. Laryngoscope 2012;122:196-203.

Olze H, Szczepek AJ, Haupt H, Förster U, Zirke N, Gräbel S, Mazurek B: Cochlear implantation has a positive influence on quality of life, tinnitus, and psychological comorbidity. Laryngoscope 2011;121:2220-2227.
O’Neill C, O’Donoghue GM, Archbold, SM, Normand C: A cost-utility analysis of pediatric cochlear implantation. Laryngoscope 2000; 110:156-160.

O'Neill C, Archbold SM, O'Donoghue GM, McAlister DA, Nikolopoulos TP: Indirect costs, cost-utility variations and the funding of paediatric cochlear implantation. Int J Pediatr Otorhinolaryngol 2001;58:53-57.

O’Neill C, Lutman ME, Archbold SM, Gregory S, Nikolopoulos TP: Parents and their cochlear implanted child: questionnaire development to assess parental views and experiences. Int $J$ Pediatr Otorhinolaryngol 2004;68:149-160.

Orabi AA, Mawman D, Al-Zoubi F, Saeed SR, Ramsden RT: Cochlear implant outcomes and quality of life in the elderly: Manchester experience over 13 years. Clin Otolaryngol 2006;31:116-122

Palmer CS, Niparko JK, Wyatt JR, Rothman M, de Lissovoy G: A prospective study of the costutility of the multichannel cochlear implant. Arch Otolaryngol Head Neck Surg 1999;125: 1221-1228.

Patrick DL, Edwards TC, Skalicky AM, Schick B, Topolski TD, Kushalnagar P, Leng M, O'Neill-Kemp AM, Sie KS: Validation of a quality-of-life measure for deaf or hard of hearing youth. Otolaryngol Head Neck Surg 2011;145:137-145.

Perez-Mora R, Lassaletta L, Castro A, Herran B, San-Roman-Montero J, Valiente E, Gavilan J: Quality of life in hearing-impaired children with bilateral hearing devices. B-ENT 2012;8: 251.

Ramos A, Guerra-Jimenez G, Rodriguez C, Borkoski S, Falcon JC, Perez D: Cochlear implants in adults over 60: a study of communicative benefits and the impact on quality of life. Cochlear Implants Int 2013;14:241-245.

Ravens-Sieberer U, Bullinger M: Assessing health-related quality of life in chronically ill children with the German KINDL: first psychometric and content analytical results. Qual Life Res 1998;7:399-407.

Rembar SH, Lind O, Romundstad P, Helvik AS: Psychological well-being among cochlear implant users: a comparison with the general population. Cochlear Implants Int 2012;13: 41-49.

Rembar S, Lind O, Arnesen H, Helvik AS: Effects of cochlear implants: a qualitative study. Cochlear Implants Int 2009;10:179-197.

Riley AW, Forrest CB, Rebok GW, Starfield B, Green BF, Robertson JA, Friello P: The Child Report Form of the CHIP-Child Edition. Med Care 2004;42:221-231.

Sach T, O'Neill C, Whynes DK, Archbold SM, O'Donoghue GM: Evidence of improving cost-effectiveness of pediatric cochlear implantation. Int J Technol Assess Health Care 2003;19:421-431.

Sach TH, Barton GR: Interpreting parental proxy reports of (health-related) quality of life for children with unilateral cochlear implants. Int J Pediatr Otorhinolaryngol 2007;71:435-445.
Schorr EA, Roth FP, Fox NA: Quality of life for children with cochlear implants: perceived benefits and problems and the perception of single words and emotional sounds. J Speech Lang Hear Res 2009;52:141.

Schulze-Gattermann H, Illg A, Schoenermark M, Lenarz T, Lesinski-Schiedat A: Cost-benefit analysis of pediatric cochlear implantation: German experience. Otol Neurotol 2002;23: 674-681.

Seiber WJ, Groessl EJ, David KM, Ganiats TG, Kaplan RM: Quality of Well-Being SelfAdministered (QWB-SA) Scale. San Diego, Health Services Research Center, University of California, 2008.

Semenov YR, Martinez-Monedero R, Niparko JK: Cochlear implants: clinical and societal outcomes. Otolaryngol Clin North Am 2012;45: 959-981.

Semenov YR, Yeh ST, Seshamani M, Wang NY, Tobey EA, Eisenberg LS, Quittner AL, Frick KD, Niparko JK; CDaCI Investigative Team: Age-dependent cost-utility of pediatric cochlear implantation. Ear Hear 2013;34:402412 .

Sparreboom M, Snik AF, Mylanus EA: Sequential bilateral cochlear implantation in children: quality of life. Arch Otolaryngol Head Neck Surg 2012;138:134-141.

Spencer LJ, Tomblin JB, Gantz BJ: Growing up with a cochlear implant: education, vocation, and affiliation. J Deaf Stud Deaf Educ 2012;17: 483-498.

Stacey PC, Fortnum HM, Barton GR, Summerfield AQ: Hearing-impaired children in the United Kingdom. I. Auditory performance, communication skills, educational achievements, quality of life, and cochlear implantation. Ear Hear 2006;27:161-186.

Steiner CA, Powe NR, Anderson GF: Coverage decisions for medical technology by managed care: relationship to organizational and physician payment characteristics. Am J Manag Care 1996;2:1321-1331.

Summerfield AQ, Barton GR: Getting acceptable value for money from bilateral cochlear implantation. Cochlear Implants Int 2003; 4(Suppl 1):66-67.

Summerfield AQ, Barton GR, Toner J, et al: Selfreported benefits from successive bilateral cochlear implantation in post-lingually deafened adults: randomised controlled trial. Int J Audiol 2006;45(Suppl 1):S99-S107.

Summerfield AQ, Lovett RES, Bellenger H, Batten G: Estimates of the cost-effectiveness of pediatric bilateral cochlear implantation. Ear Hear 2010;31:611-624.

Summerfield AQ, Marshall DH, Barton GR, Bloor KE: A cost-utility scenario analysis of bilateral cochlear implantation. Arch Otolaryngol Head Neck Surg 2002;128:1255-1262.

Thebaut C: Dealing with moral dilemma raised by adaptive preferences in health technology assessment: the example of growth hormones and bilateral cochlear implants. Soc Sci Med 2013;99:102-109. 
UK Cochlear Implant Study Group: Criteria of candidacy for unilateral cochlear implantation in postlingually deafened adults II: costeffectiveness analysis. Ear Hear 2004;25:336360.

Vermeire K, Brokx JPL, Wuyts FL, Cochet E, Hofkens A, Van De Heyning PH: Quality-oflife benefit from cochlear implantation in the elderly. Otol Neurotol 2005;26:188-195.

Warner-Czyz AD, Loy B, Roland PS, Tong L, Tobey EA: Parent versus child assessment of quality of life in children using cochlear implants. Int J Pediatr Otorhinolaryngol 2009; 73:1423-1429.
Warner-Czyz AD, Loy B, Tobey EA, Nakonezny P, Roland PS: Health-related quality of life in children and adolescents who use cochlear implants. Int J Pediatr Otorhinolaryngol 2011;75:95-105.

Weinberg N, Sterritt M: Disability and identity: a study of identity patterns in adolescents with hearing impairments. Rehabil Psychol 1986; 31:95-102.
Wyatt JR, Niparko JK, Rothman M, deLissovoy G: Cost utility of the multichannel cochlear implant in 258 profoundly deaf individuals. Laryngoscope 1996;106:816-821.

Zhao F, Bai Z, Stephens D: The relationship between changes in self-rated quality of life after cochlear implantation and changes in individual complaints. Clin Otolaryngol 2008;33: 427-434.

Zullig KJ, Matthews MR, Gilman R, Valois RF, Huebner ES: Generic quality of life measures for children and adolescents; in Preedy VR, Watson RR (eds): Handbook of Disease Burdens and Quality of Life Measures. New York, Springer, 2010. 